ISSN 2587- 2001 e-ISSN 2618-6187

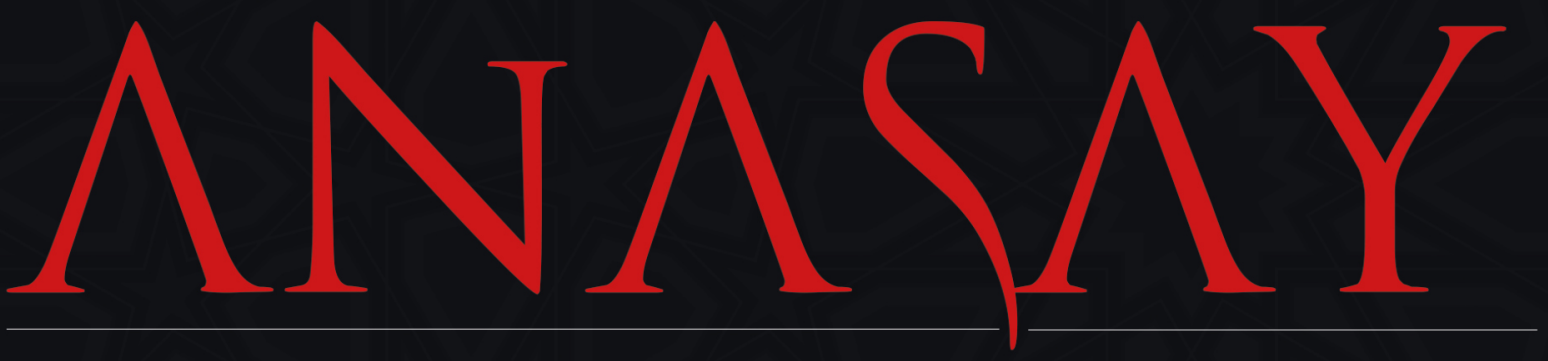

3 Aylık Ulusal Hakemli - Süreli Dergi -Yı1:3 - Sayı:7 - Şubat 2019

\title{
koynunda büyüdük
}

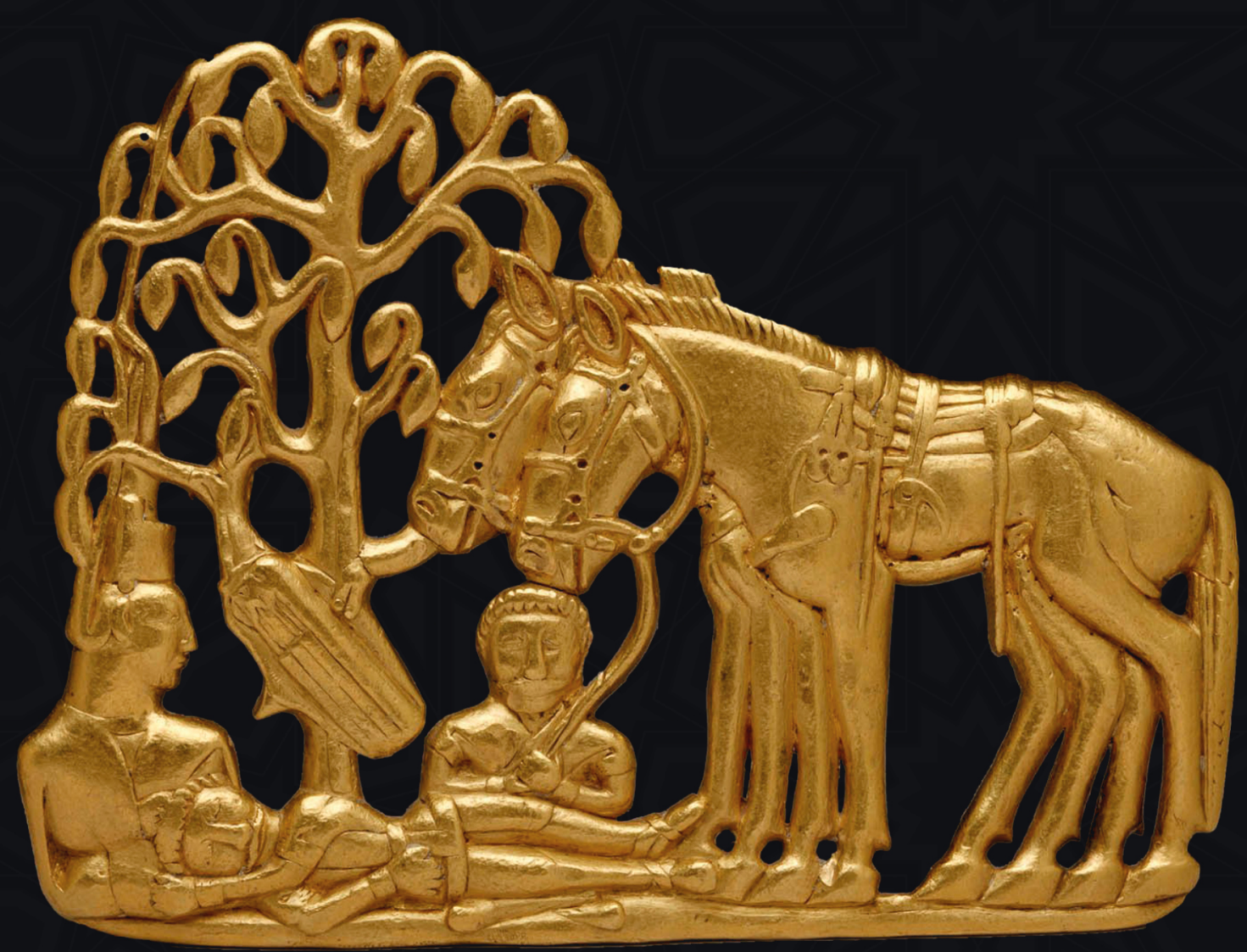




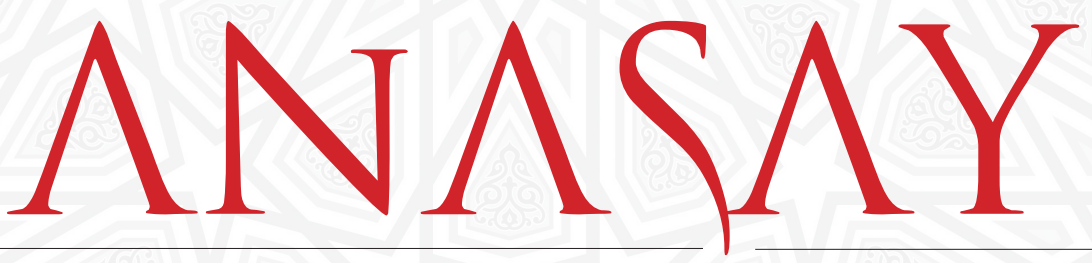

3 Aylık Ulusal Hakemli - Süreli Dergi - ISSN 2587- 2001 e-ISSN 2618-6187 


\section{IÇCINDEKILER}

Ramazan KILIÇ .11

YABANCI DİL ÖĞRETIMINDE ANADIL - HEDEF DILL YAPILARININ BAŞARIYA ETKİİ

THE EFFECT OF MOTHER TONGUE-TARGET LANGUAGE ON SUCCES OF FOREIGN LANGUAGE TEACHING

Nurullah KIRKPINAR 29

MILLII MÜCADELE YILLARINDA BOLŞEVIZM PROPAGANDASI VE ANADOLU BASINI 1919-1922

BOLSHEVISM PROPAGANDA IN THE YEARS OF NATIONAL STRUGGLE AND ANATOLIAN PRESS 1919-1922

Nesrin GÜLLÜDAĞ - Halit BAŞ. .73

1452 NUMARALI İZMITT ŞERIYE SICCILINDE YER ALAN UNVAN VE LAKAPLAR ÜZERINE BIR INCELEME

A STUDY ON TITLES AND PSEUDONYMS IN THE SHARIA COURT REGISTERS OF IZMIT, REGISTRY NO 1452

Rukiye ÖZDEMIR - Ahmet AYDIN 105

OSMANLITARIIH YAZICILIĞINDA MUHTASAR UMUMI TARIIHLER ÜZERINE

ON THE SUMMARY GENERAL-HISTORY WRITINGS IN THE OTTOMAN HISTORIOGRAPHY

Muhammet Ali HOROZ

17. YÜZYIL BAŞLARINDA GALATA'YA GELENTICARİ ÜRÜNLER VE GALATA GÜMRÜK BÖLGESI

EARLY 17th CENTURY COMMERCIAL PRODUCTS INCOMING TO GALATA AND GALATA CUSTOMS TERRITORY 
Mayrambek OROZOBAYEV

KIRGIZLARDAKİ AŞIKLIK GELENEĞİNIN YENIDEN DOĞUŞU ÜZERINE

ON THE REBIRTH OF THE TRADITION OF MINSTRELSY IN KYRGYZ

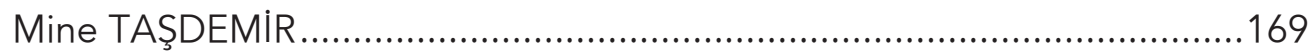

SA 'DU'LLÂH EL-HALVETÎ'YE ATFEDIILEN ANONIM KASIIDE-İ BÜRDEŞERHIINE GÖRE NEFSIN MAHIYETIVEÖZELLİKLERI

THE FEATURE AND CHARACTERISTICS OF THE NAFS ACCORDING TO THE COMMENTARY KASIDE-I BÜRDE ATTRIBUTED TO SA 'DU'LLÂH EL- HALVETÎ 


\title{
OSMANLITARİHYAZICILIĞINDA MUHTASAR UMUMI TARIIHLER ÜZERINE ${ }^{{ }^{*}}$
}

ON THE SUMMARY GENERAL-HISTORY WRITINGS IN THE OTTOMAN HISTORIOGRAPHY

DOI: 10.33404/anasay.512209

\author{
Çalışma Türü: Araştırma Makalesi / Research Article
}

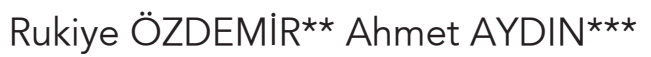

\section{ÖZET}

Umumi Tarihler genel olarak insanlığın yaratılıştan başlayarak İslâm tarihi, Osmanlı öncesi ve çağdaşı devletler ile Osmanlı tarihi hakkında geniş ölçekli bir yelpazeyi içerir. Bu eserler genel anlamda hemen hemen aynı muhtevaya sahip olmakla birlikte içeriklerinin sunum şekilleri açısından farkl1lıklar göstermektedirler. Bu nedenle umumi tarihler kendi aralarında mufassal ve muhtasar umumi tarihler olarak gruplandırılabilir. Bunlardan mufassal olanlar içeriklerini ayrıntılı bir şekilde sunmuşlardır. Bunun en güzel örneklerini Gelibolulu Mustafa Ali'nin “Künhü'l Ahbar” ve Kâtip Çelebi’nin Fezleketü'l akvâli'l-ahyâr

1- Makale Geliş Tarihi: 18. 01. 2019 Makale Kabül Tarihi: 29. 01. 2019

* Bu makale Atatürk Üniversitesi Türkiyat Araştırmaları Enstitiüsü Tarih Ana Bilim Dalı bünyesinde tamamlanan Ramazân-zâde'nin Târîh-i Nişâncı Paşa İsimli Eserinin Tahlil Ve Metin Tenkidi adlı doktora tezinden derlenmiştir.

** Dr. rukiyeozdemir2715@gmail.com, Gaziantep.

*** Dr. Ögr. Üyesi, Ağr1 İbrahim Çeçen Üniversitesi Eğitim Fakültesi, aaydin@agri.edu.tr 
fi'ilmi’t-târîh ve'l-ahbâr (Arapça Fezleke) / Takvîmü't-Tevârih (Türkçe Fezleke) adlı eserlerinde görmek mümkündür. Muhtasar umumi tarihler ise içeriklerini özet-hülasa bir biçimde kronolojik esaslı olarak oluşturmuşlardır. Bunun örnekleri arasında ise Mevlana Şükrullah'ın Behçetü't-Tevârih, Ramazân-zâde Nişâncı Mehmed Paşa'nın Târîh-i Nişâncı Paşa ve Cenâbî Mustafa Efendi' nin El-Aylemü'z-Zahir veya Gülşen-i Tevârîh, Hezârfen Hüseyin Efendi'nin Tenkîh-i Tevârih-i Mülük adlı eseri sayılabilir.

Bu çalışmada muhtasar olarak kaleme alınan Behçetü’t-Tevârih, Târîh-i Nişânc1 Paşa, Gülşen-i Tevârîh ve Tenkîh-i Tevârih-i Mülûk eser-müellif eşleştirmeleri tanıtılmıştır. Ayrıca muhtasar olarak yazılan eserlerde olayların özet-hülasa şekilde anlatım içerik örneklerine yer verilmiştir. Bu örnekler vasıtasıyla muhtasar umumi tarihlerin ortak yönlerinin olayların ayrıntısını vermekten ziyade kapsam geçerliliğine önem verdiklerini göstermek ve daha fazla bilgi sunmayı amaçladıklarının izahı çalışmalarına katkıda bulunulmak hedeflenmiştir. Bununla birlikte verilen içerik örnekleriyle muhtasar umumi tarihlerin birbirlerinden ayrılan yönlerinin temelde hangilerinin muhtasarlık içinde kısmi mufassallığa yöneldiği hangilerinin ise muhtasarlık içinde daha da muhtasarlığa yöneldiği incelenmeye çalışılmıştır.

Anahtar Kelimeler: Osmanlı Tarih Yazıcılığı, Umumi Tarihler, Muhtasar Umumi Tarihler, Ramazân-zâde, Târîh-i Nişâncı Paşa.

\section{ABSTRACT}

Starting with the history of humanity, the General History includes a wide array of issues ranging from the Islamic history, pre-Ottoman period, its contemporary states and the Ottoman history. Although these works generally have a similar content, there are differences in the presentation styles of their contents. Therefore, the pieces of general history are classified in two groups as detailed and summary general history writings. The detailed ones presented their contents in detail. Among this type, the best examples can be observed in the "Künhü'lAhbar" of Gelibolulu Mustafa Ali (lit.Mustafa Ali from Gallipoli), and 'Fezleketü'l akvâli'l-ahyâr fi'ilmi’t-târîh ve'l-ahbâr (Arabic Record) / Takvîmü’t-Tevârih (Turkish Record)" of Kâtip Çelebi. As per the summary general history writings, they were chronologically formed in a summary-extract manner. Among its examples are "Behçetü't-Tevârih" of Mevlana Şükrullah, "Târîh-i Nişâncı Paşa" of Ramazân-zâde Nişânc1 Mehmed Paşa, "El-Aylemü'z-Zahir" or "Gülşen-i Tevârîh” of Cenâbî Mustafa Efendi, and "Tenkîh-i 
Tevârih-i Mülük” of Hezârfen Hüseyin Efendi.

In this study, the writing-author matchings of the following works are introduced: "Behçetü’t-Tevârih", "Târîh-i Nişâncı Paşa”, "Gülşen-i Tevârîh", and "Tenkîh-i Tevârih-i Mülûk". Additionally, in the works committed to paper as summary, the content examples of summary-extract are presented. Through these examples, it was aimed to show that the shared aspects of these works was to attach more importance to the content validity rather than conveying the details of the events, and to contribute to the studies attempting to present that they were aiming to provide as much information as possible. Furthermore, within the differences of detailed and summary general history writings, through the content examples, it was attempted to investigate which of them tended to partial "detailed-ness" within "summary-ness" and which of them tended to even more "summary-ness" within the "summary-ness".

Key Words: Ottoman Historiography, General History Writings, Summary General Historiography.

\section{Giriş}

İnsanların zaman ve mekân içindeki geçirdikleri gelişmeleri ve bu insanların psiko-fizik hareketlerini, bu hareketlerin sebep-netice münasebetine dayanan ortak değerleri araştıran (Baykara 2010: 10) bir bilim olarak tarif edilen ve Arapça'dan Türkçe'ye geçen Tarih kelimesinin kökeni hakkında birçok görüş öne sürülmüştür. Kelime Arapça olmamakla birlikte, Arapça'ya da Sami dillerinden Akadca'da "Erhu (Ay, Kamer)", (Şeşen 1998: 9) Sabii dilinde, Habeşce'de ve İbranice'de "Yereah / Yerah" kelimelerinden "Erreha / Verraha" fiili türetilerek "Târîh (تاريخ) / Te’rîh (تأريخ) imlasıyla girmiştir. Bu anlamıyla Tarih kelimesi, "geçmişteki bir noktayı veya geçmişte meydana gelen hadiselerin tamamını, tarihî bir olayın meydana geliş zamanını, kronolojisini ve olaylar dizisini tespit etmek" anlamlarına gelmektedir. (Fayda 2011: 30)

Osmanlı Devleti'nde tarih yazımı, kuruluş tarihine göre oldukça geç başlamıştır. Bu nedenle XIII. yüzyılın sonu ve XIV. yüzyılın başlarına kadar yazılı herhangi bir Osmanlı tarihi bulunmamaktadır. Osmanlı dışındaki diğer coğrafyalarda da Osmanlı Devleti'nin kuruluş dönemine dair tarih yazımı konusunda eserler oldukça azdır. (Afyoncu 2003: 101) Bu dönem Osmanlı devletine ait bilgiler Bizans tarihçilerinden Pachymeres Nicephoras ve Kantakousenos ile Arap seyyahlarından İbn Battûta, ibn-i Said ve El-Ömerî'den öğrenilmektedir (Afyoncu 2009: 3). 
XV. yüzyılın ilk yarısında yazılan ilk eser olarak Yahşi Fakih'in Menâkıb-1 Âl-i Osmân adlı eseri kabul edilmektedir. Yahşi Fakih'in eserinin varlığından Âşıkpaşazâde'nin yazmış olduğu Âşıkpaşazâde Tarihi vasıtasıyla haberdar olunmaktadır. $^{2}$ (Öztürk 2013: 3) Yahşi Fakih eserini kendi müşahedelerine ve babasından duyduğu hadiseleri de eklemiş olmalıdır (Afyoncu 2009: 3). Bu menakıb-nâme daha sonra oluşturulan Anonim Tevârih-i Âl-i Osmânların kullandığı en önemli kaynak olmuştur (Menage 1963: 50).

Osmanlı tarih yazıcılığının günümüzde mevcut olan ilk örneği XV. yüzyıl başlarında Şair Ahmedî tarafından kaleme alınmıştır. Eser onbin beyitli mesnevi tarzında Süleyman Şah adına hazırlanmış olan İskender-nâme adlı eserin son kısmındaki Dâsıtân-ı Tevârih-i Âl-i Osmânı'dır ( Aydın 2002: 417; Akçay 1999: 3).

II. Murad dönemi tarih yazıcıllı̆̆ için oldukça önemlidir. Zira bu dönemde Arapça ve Farsça eserler Türkçe’ye çevrilmiştir. Bu alandaki en önemli örnek İranlı şair ve tarihçi İbn Bîbî'nin el-Evâmirü'l-Alâiyye fi'l-Umûri'l-Alâiyye'sidir. Farsça olarak yazılmıştır. Türkiye Selçuklularıyla ilgili bilgiler vermektedir. Eser XV. yüzyılın ilk yarısında Yazıcı-zâde Ali tarafından Türkçe'ye çevrilmiştir. (Başar 2002: 409-416) Müellif tarafından eserin başına Oğuz-nâme bölümü eklendiği gibi Melik Cüveynî’ye methiye bölümü yerine II. Murad'a ait methiyeler oluşturmuştur. (Bakır 2014: 6-7 ) Ayrıca Osmanlı tarihçiliğinin en önemli kaynaklarından olan Anonim Tevârih-i Âl-i Osmânlar³, Gazâ-nâmeler (Gazâvât-nâmeler) ${ }^{4}$ ve Tarihi takvimler ${ }^{5}$ de bu döneme aittir. (Öztürk 1999: 257).

2- 'Orhan Gazi'nin imamı İshak Fakı oğlu Yahşi Fakı'dan kim ol Sultan Bayezıd Hân'a gelince bu menakıbı ol Yahşi Fakı'dan yazılmış buldum kim o, Orhan Gazi’nin imamı oğludur.” Bkz. (Öztürk 2013:3).

3- Anonim Tevârih-i Âl-i Osmânlar, II. Murad döneminde oluşmaya başlayan ve II. Bayezid (14811512) döneminde yazılmaya başlanan ilk kroniklerdir. Muhteva bakımından Anonim Tevârîh-i Âl-i Osmân'lar tamamlanış yıllarına göre üç grupta ele alınabilir. İlk grup genelde 1494'e kadar gelen ve II. Bayezid devrinde derlenmiş olanlardır. İkinci grup 1555 yılına kadar gelir. Üçüncü grup XVII. yüzyıla sarkan yazmalardan oluşmaktadır. Bkz. (Özcan 2011: 579-580). Avrupa'daki nüshalar hakkında Bk. Neşr. F. Giese, Haz. 1992: XIII, XVIII-XXVI; Türkiye'deki nüshalar hakkında Bkz. (Öztürk 2015: XXVI-XXVIII).

4- Bu türdeki eserleri üç gruba ayırarak incelemek mümkündür. Bunlardan birincisi padişahları merkeze alarak onun zamanındaki gazaları anlatır ki bunlar genellikle Selim-nâmeler ve Süleyman-nâmeler olarak adlandırılmıştır. İkinci grup gazavat-nâmeler ünlü komutan veya devlet adamlarının gazalarını anlatır ki bunların örnekleri arasında Gazavat-1 Tiryaki Hasan Paşa, Ebubekir bin Abdullah'ın Şark Seferleri adlı eseri örnek gösterilebilir. Üçüncü grup gazavat-nâmeler ise bir şehir veya kalenin feth edilmesiyle ilgili gazaları anlatır ki bunun en güzel örneği Kemalpaşa-zâdenin Tarih-i Fethi Konstantiniyye adlı eseridir. Bkz. (Süleyman Lokmacı 2017: 665- 677).

5- Kuruluş devri tarih kaynakları arasında yer alan Takvimler ise İslâmî dönem astronomisinin son tipik örneğini teşkil etmiştir. Müneccimler tarafından hazırlanan takvimlerde siyasi ve tabiî olaylar kronolojik liste şeklinde verilmiş, bu yönüyle ilk vak'anüvislik çalışmalarına benzetilebilir. Bu tarihi takvimlerin bir kısmının neşirleri Nihal Atsız ve Osman Turan tarafından yapılmıştır. Bkz. (Özcan 2013: 271-293). Bu takvimlerden en eskisi 824 (1421) tarihli olub Farsçadır. Diğerleri ise 835 (1431), 843 (1439), 848 (1444) ve 850 (1446) tarihlidir. 1452 tarihli takvim ise Fatih Sultan Mehmed döneminde hazırlanıp padişaha sunulmuştur. Bkz. (Afyoncu 2009: 4). 
Fatih Sultan Mehmet döneminde İstanbul'un fethi ve sonrasında hem siyasi hem coğrafi hem de kültürel olarak yaşanan gelişmeler beraberinde tarih yazıcılığında bir canlanmayı getirmiştir. Bu dönemde Enverî’nin Düsturnâmes'i, Mevlana Şükrullah'ın Behçetü't-Tevârih'i, Karamânî Mehmed Paşa'nın Tevârihü's-Selâtini'l-Osmaniyye'si, Tursun Bey'in Târîh-i Ebü'l-Feth'i, ilk teşkilat kanun-nâmesi olan Kânûn-nâme-i Âl-i Osman yazılmıştır (Özcan 2003: 55; Öztürk 2015: 21). Yine bu dönemde şehnâme adı verilen ve bir tür yarı resmi saray tarihçiliği olarak kabul edilen yazma geleneği de başlamıştır (Woohead 2010: 456). İran şehnâmeciliğinden etkilenerek devrin padişahını övmek amacıyla yazılmış olan bu eserlerin ilk örneğini Fatih tarafından görevlendirilen Şehdî oluşturmaya çalışmıştır. Ancak Şehdî bu alanda pek başarılı olamamıştır (Asim 1329: 425-428).

II. Bayezid dönemi (1481- 1512) ise tarih yazıcılığında belli bir sistem ve nizamın uygulandığı dönem olmuştur. ( Öztürk 2015: 21) Bu dönemde Aşıkpaşa-zâde-Menakıb-1 Âl-i Osman adlı eserini yazmıştır. Eserin en önemli yönü ilk standart Osmanlı tarihlerindendir. Eser 1285-1502 yıllarındaki olayları kapsayan üç bölümden oluşmaktadır (Özcan 2013: 146; Öztürk 2013: 30). Mevlana Mehmed Neşri'nin Cihânnümâsı, altı bölümden oluşan dünya tarihi niteliğinde olup günümüze sadece altıncı bölümü ulaşmıştır. Bu bölüm ise kendi arasında dört tabakaya ayrılmıştır. Birinci tabaka olan Kısm-1 Sadis’te Tüklerin kökeni anlatılmıştır. İkinci kısım olan Tabaka-i Ulâ'da Oğuz Han ve Selefleri konu edinilmiştir. Üçüncü bölüm olan Tabaka-i Sâniye'de Karahanlılar, Anadolu Selçuklular ile Karamanoğullarına yer verilmiştir. Dördüncü kısım olan Tabaka-i Sâlise ise Osmanlılara ayrılmıştır (Özcan, 2007: 21; Öztürk, 2013: XXXVII). İdris-i Bitlisî'nin Heşt Behişt'i, Osmanlı devletinin kuruluşundan Yavuz Sultan Selim'in ilk yıllarına kadar gelir. Eser bir Mukaddime ve her padişaha ayrılmış sekiz ketibe ve bir hâtimeden oluşmakta olup hatime kısmı esere sonradan eklenmiştir. Eser oldukça süslü bir şekilde Farsça olarak yazılmıştır (Özcan 1998: 271-273). Kemalpaşa-zâde'nin Tevârih-i Âl-i Osman'1, II. Bayezid'ın emri ile her padişaha bir cilt ayıracak şekilde yazılmıştır. Ancak daha sonra Kanuni Sultan Süleyman'ın isteği üzerine esere devam edilerek Mohaç Seferinin sonuyla on cilde tamamlanmıştır. Fakat dokuzuncu ve onuncu ciltlerde Yavuz Sultan Selim ve Kanuni Sultan Süleyman dönemini ihtiva eden konularda eksiklikler mevcuttur (Turan 2002: 238-240). Oruç Beğ'in Tevârih-i Âl-i Osman'1, Osmanlı devletinin kuruluşundan 908 / 1502 yıllarına kadar gelen olayları içermektedir 
(Özcan 2007: 425). Ruhi Çelebi'nin Tevârih-i Âl-i Osman'1 II. Bayezıd'ın isteği ile kaleme alınmıştır. Osmanlı Devletinin kuruluşından Şehzade Selim'in 1511 yılında II.Bayezıd'a karşı karşı saltanat mücadelesine kadar gerçekleşmiş siyasi ve askeri olayları içermektedir (Özergin 1963: 764-765).

II. Bayezıd'dan sonra XVI. yüzyılda tarih yazıcılı̆̆ı gelişimine devam etmiştir. Hoca Sadeddin Tacü’t-Tevârih adlı eserinde Osmanlının kuruluşundan Yavuz Sultan Selim döneminin sonuna kadarki olayları anlatmıştır (Turan 1998: 198). Peçevî İbrahim Efendi, Peçevî Tarihi'nde Kanunu Sultan Süleyman'in saltanatının ilk yıllarından (1520 ) IV. Murad döneminin sonuna kadarki (1639) olayları anlatmıştır. Ayrıca siyasi olaylar dışında barut yapımı, matbaa'nın keşfi, tütün ve kahve kullanımının yaygınlaşması, yıldız bilimi, her padişah dönemindeki devlet erkânı, ulema ve şeyhler hakkında bilgilerde içermektedir. $\mathrm{Bu}$ yönüyle eser yüksek zümre ile halk zümresi kültürlerinin karışımı niteliğindedir (Hancz 2017: 217-218; Öztürk 2015: 114). Selânikî Mustafa'nın Târih-i Selânikî'si Kanunu Sultan Süleyman döneminin ortaları ile II. Mehmed'in saltanatının ortalarına kadar olan olayları ihtiva etmekte olup olayları hatırat şeklinde kendi yorumlarını katarak anlatmıştır (İpşirli 2009: 358).

XVI. yüzyılda görülen diğer bir yenilik ise Yavuz Sultan Selim döneminin anlatıldığı Selim-nâme yazma geleneğinin başlamasıdır. Bu türden eserler genellikle Yavuz Sultan Selim'in Trabzon'daki valiliğinden başlayarak dışta Gürcülerle mücadelesi içte babası, kardeşleriyle olan taht mücadelesinin ardından tahta geçişle birlikte Safevilerle giriştiği savaşlardan bahseden eserlerdir (Tekindağ, 1970:197). Bu türün önekleri arasında İdrisî Bitlisi’nin ve Celal-zâde Mustafa Çelebi'nin eserleri sayılabilir. Bu gelenek daha sonra Kanuni'nin tahta çıkmasıyla Süleyman-nâmeler şekline dönüşmüştür. Kanuni Sultan Süleyman'ın tahta geçtiği 1520 yılından başlayıp saltanatı boyunca seferlerini ve dönemin diğer olaylarını anlatır. Süleymannameler kendi aralarında zamanla genişletilip eklemelerle yeniden düzenlendiği gibi (Bostan Çelebi'nin Süleymannamesi) birbirini takip eden farklı isim ve cüzler halinde kaydedilen fakat neticede bir Süleymannameyi oluşturan (Matrakçı Nasuh'un Süleymannamesi) eserlerde mevcuttur. Bir diğer Süleymanname çeşidi ise Kanuni 'nin saltanat1nın sonlarına doğru yazılan ve geçen sürede telif edilmiş tarihlerden ve ve diğer resmi belgelerden faydalanılarak terkip şeklinde ( Gubârî ve Ârifî’nin Süleymannamesi ) yazılanlardır (Sağırlı 2010: 124-125). 
XVII. yüzyılda ise Solak-zâde Mehmed Hemdemî "Solak-zâde Tarihi”ni yazmıştır. Eser Osmanlının kuruluşundan I. Ahmet'in vefatına kadar gerçekleşen siyasi ve askeri olayları içermektedir. Eser tüm nüshalarda aynı yerden başlasa da bitişi nüshalara göre farklılık göstermektedir. Konuyla ilgili diğer kaynaklarda da eserin bitişiyle ilgili ortak bir kanaat yoktur. Tüm nüshaları aynı yerde bitmediğinden, birkaç telif aşaması geçirdiği düşünülmektedir (Lokmacı 2015: 4). Hasanbey-zâde; "Beyzâde Tarihi" olarak tanınan iki ciltlik eserin sahibidir. Birinci cildi Hoca Sadeddin Efendinin Tacü’t Tevârîh adlı eserinin özeti mahiyetinde yazılmıştır. İkinci cildi ise Kanunu Sultan Süleyman döneminden IV. Murad dönemindeki olayları ihtiva etmektedir. III. Mehmed döneminden sonra müellif olaylara bizzat tanık olduğu için eser orijinaldir (Aykut 1997: 363364).

XVIII. yüzyıl başında tarih yazıcılığında Osmanlılar'da resmî tarihçiliğin bir devlet görevi olarak vakâyi'vünisliğin ihdası ve memuriyete dönüşmesi Amca-zâde Hüseyin Paşa'nın sadrazamlığı dönemine rastlamıştır. Vakâyi‘vünisler sadece kendi dönemlerinin olaylarını yazmakla kalmamış, olayların kesintisiz tesbiti için seleflerinin eksik bıraktıkları devrin tarihini tamamlamakla da görevlendirilmiştir (Kütükoğlu, 2012: 457-458). Bu dönemde Mustafa Naîmâ Efendi-Ravzatü'l-Hüseyin fî̀ hulasâti ahbari'l-hâfikayn (Naîmâ Tarihi), Sadullah Enverî Efendi-Enverî Tarihi, Ahmed Vâsıf Efendi-Mehâsinü’l-âsâr ve Hakā'ikü'l-ahbâr adlı eserlerini oluşturmuşlardır (Özcan 2013: 281-282). Mustafa Naîmâ Efendinin eseri; kronolojik olarak tertib edilmiş, roman tarzına yakın nükteli, imalı bir anlatımla Osmanlı Devleti'nin 1574-1659 yılları arasındaki olayları içermektedir (Ípşirli 2006: 316.). Sadullah Enverî Efendi'nin Enverî Tarihi üç ciltten oluşmuş bir eserdir (Aktepe 1995: 269). Birinci cildi H. 1182-1888/M. 1768-1774 arası vekāyi ‘i konu almaktadır. İkinci cildinde H 1188-1197 / M 1774-1783 arasındaki vekāyi‘den oluşmaktadır. Eserde dönemin iç politikası, Sultan I. Abdülhamid'in çocukları, dönemin önde gelen devlet görevlilerinden vefat eden kişilerin biyografileri, ekonomik tedbirlere yönelik uygulanan yasaklar, Kırım ekseninde gelişen Osmanl1-Rus münasebetleri, Osmanl1-İran münasebetleri, İstanbul'da meydana gelen yangınlar vs. konuları anlatılmaktadır. Üçüncü cildi ise H 1201-1206 / M 1787-1792 y1lları arasını kapsamaktadır (Çiçek 2018: 257).

Ahmed Vâsıf Efendi'nin Mehâsinü'l-âsâr ve Hakā'ikü'l-ahbâr'1 H 1197/ M 1783 yılı olaylarının bakiyesi ile başlamakta ve H 1201 / M 1786-1787 olayları ile son bulmaktadır (Çiçek, 2018: 377-406) Vasıf Efendi, bu eseri hazırlar- 
ken öncelikle Sadullah Enverî’nin Enverî tarihini kaynak olarak kullanmıştır. Enverî Tarihi'ndeki bütün belge suretlerini çıkarmıştır. Daha sonra burada mevcut konuların başlıklarından bazılarını aynen, bazılarını küçük değişikliklerle, bazılarını değiştirerek, büyük bir oranda da başlıkları birleştirerek ve kısaltarak eserine nakl etmiştir. Eserin bazı vefayat kısımlarında ve başlıklarda kendisinin eklediği bilgiler mevcuttur. Bunlar haricinde kalan kısımları şekil açısından değiştirilerek ve içerik açısından da kimi zaman özet şeklinde ve kimi zaman da mealen kaydetmiştir ( Çiçek 2018:118)

XIX. ve XX. yüzyılda ise Antepli Mütercim Âsım Efendi Burhân-1 Kâtı‘ ve Kâmus Tercüme sözlükleri ile Tuhfe-i Âsım adlı Arapça sözlük yazmıştır. Bunun dışında Tarih-i Âsım adlı eserinde 1778-1808 yılları arasındaki olaylar1 anlatmıştır. (Kaçalin 2006: 200-202) Ahmed Cevdet Paşa, Tarih-i Cevdet'de 1774 Küçük Kaynarca Antlaşmasından 1826 Yeniçeri Ocağının kaldırılmasına kadarki olayları anlatmıştır. Bu eseri diğer vakâyi'vünis tarihlerinden ayıran ve önemli kılan unsur Avrupa tarihine de yer verilmiş olmasıdır (Halaçoğlu-Aydın 1993: 448) Ayrıca Târih-i Cevdet'in kullandığg kaynakların çeşitliliğii ${ }^{6}$, kaynak olarak kullandığı vekāyi‘nüvislerin eserlerindeki eksiklik ve hatalı kısımları düzeltip eklemeler yaparak eserini meydana getirmiştir (Çiçek 2018: 196) Abdurrahman Şeref vakâyi'vünislik yaptığı sırada oluşturduğu Vekayi‘nâme adlı eserinde 1908-1918 yılları arasındaki olayları anlatmıştır. (Özcan 1998: 175) Ahmed Vefik Paşa'nın Fezleke-i Tarih-i Osmanî’si ise Rüştiyelerde okutulmak amacıyla hazırlanmış olan ilk ders kitabıdır. Eser başlangıçtan Abdülaziz'e kadar Osmanlı konularını ihtiva eden kuruluş, büyüme, yükselme, gerileme, bozulma, ıslahat çağı olarak altı bölümden oluşan üçyüz sayfalık bir kitapdır. $\mathrm{Bu}$ eserin en önemli yönü Osmanlı tarihinin okul müfredatına ilk kez girmesi ve Osmanlı soyunun Kayı kelimesi ile değilde Türk kelimesi ile ifade edilmiş olmasıdır (Akün 1998: 151-152).

\section{Umumi Tarihler}

XV. yüzyıldan itibaren oluşturulmaya başlanan Tevârih-i Âl-i Osmânlar geleneğinde, kuruluştan itibaren her padişah dönemine ait siyasi, ekonomik, sosyal alanlarda bilgiye ulaşmak mümkündür. Tevârih-i Âl-i Osmanlar Osmanlı

6- 'Osmanlı vekāyi 'nüvisleri içerisinde mümtaz bir yere sahip olan Ahmed Cevdet Paşa'nın, 1188 (1774) ve 1240 (1824) yılları arasındaki olayları anlatan Târih-i Cevdet’inin kaynaklarının başında vekāyi‘nüvis tarihleri gelmektedir. Ayrıca özel tarihler, mecmua, layiha, teracim-i ahval kitapları, seyahatnâmeler, sefaretnâmeler, antlaşma metinleri, telhisler, arşiv belgeleri, hatt-1 hümayunlar eserin birinci elden kaynakları arasındadır. Bunların dışında mezar taşları, vakfiye ve sikke gibi malzemelerin tarih çalışmaları için çok önemli olduğunu kavramıştır. Yabancı dile vâkıf olduğu bilinen Cevdet Paşa, eserinde Batılı kaynakları kullanmayı da ihmal etmemiştir.” Bkz. (Çiçek 2018: 185). 
tarih yazımında ne kadar büyük bir öneme sahip ise evrensel ya da umumi tarih olarak adlandırılan geniş çaplı eserlerinde Osmanlı tarih yazımında farklı bir yeri ve önemi vardır. Umumi tarihler Osmanlı devletini bütünsel bir yaklaşım içinde değerlendirirken, dünyanın diğer devletleriyle karşılaştırma imkanı sağlamaktadır. Bu bağlamda oluşturulan umumi dünya tarihlerinde farklı toplum ve devletlerin algılanışını ve bu algılayış içerisinde Osmanlının nasıl konumland1rildığını görmek mümkündür (Yıldız 2015: 113).

Umumi tarihler genel olarak insanlığın yaratılışından başlayarak, İslâm tarihi, Osmanlı öncesi ve çağdaş devletler ile Osmanlı tarihi hakkında geniş ölçekli bir yelpazeyi içerir. Oluşturulan bu eserler genel anlamda hemen hemen aynı muhtevaya sahip olmakla birlikte içerikleri ve sunum şekilleri açısından farklılıklar göstermektedirler. Bazı eserler içeriklerini mufassal-ayrıntılı bir şekilde sunarken, bazıları ise muhtevalarını muhtasar-özet-hülasa bir biçimde, kronolojik esaslı olarak oluşturmuşlardır.

\subsection{Mufassal Umumi Tarihler}

Mufassal kelimesi mana olarak "Tafsilli, tafsilâtlı, izahlı, geniş mâlumatl1, kısımlara ayrılıp anlatılmış” demektir. Bu tanımdan da anlaşılacağı üzere bu gruba giren umumi tarihlerde içerikler oldukça ayrıntılı bir şekilde tasvirlenmiştir. Mufassal yazılmış umumi tarih örneklerini Enverî̀ "Düstûrnâme", Muslihid-

Enverî 15. yy da yaşamış şair ve tarihçidir. Müellif hakkındaki bilinenler sadece eserinden elde edilen bilgilerdir. Gerçek adı, ailesi, nereli olduğu, nasıl bir eğitim aldığı ve hangi meslekten olduğu bilinmemekle birlikte Enverî mahlasıyla tanınmıştır. Bk. Öztürk, 2012: XXIX ; Özcan, 1994: 49-50. Orta derecede Arapça ve Farsça bildiği, daha önce Fatih Sultan Mehmed adına Teferrücnâme adlı bir kitap yazdığı eserdeki mukaddime bölümünden anlaşılmaktadır. Bu kitaptan sonra hâmisi Mahmud Paşa adına Düstûrnâme'yi hazırladığını yine eserin mukaddime bölümünde ifade etmiştir. Ayrıca Fatih döneminde Eflak ve Midilli seferlerine katılmış hatta Midilli adasının fethinden sonra ilk kez ezan onun tarafından okunmuştur. Ayrıca 1462 yılında Bosna seferine de katılmıştır. Bkz.(Özcan 1994:49-50; Ademler 2007: 5-6). Enverî Düstûrnâme'yi Zilhicce 869 ( Ağustos 1465 ) yılında yedi gün içinde tamamlayarak Veziriazam Mahmud Paşa'ya ithaf ettiğini eserinde belirtmektedir. Bkz. (Öztürk 2012: XXX).

8- Düstûrnâme mesnevi tarzda yazılmış, bir mukaddime ve yirmi iki bab'dan oluşmaktadır. Bir ve onyedinci bablarda sırasıyla: Peygamberler Tarihi, Pişdânîler, Keyâniler, Eşkânîler, Sâsânîler, Hz. Muhammed, Hulefâ-yi Râşidîn, Emeviler, Abbasiler, Saffâriler ve Sâmânîler, Gaznevîler, Deylemîler, Kûhistan Melikleri yani İsmailîler, Selçuklular, Salgurîler, Harezmşahlar ve Moğollardan bahsedilmektedir. Onsekizinci bab ise eserin büyük bir kısmını oluşturmakta ve Aydınoğulları tarihi hakkında diğer kaynaklarda olmayan bilgiler ihtiva etmektedir. Gazi Umur Beyin yirmi altı gazası ayrıntılı biçimde yine bu bab'da anlatılmıştır. Ondokuzuncu bab ise Osmanlının kuruluşunu Oğuzlardan başlatarak Fatih dönemine kadar getirdiği Osmanlı Tarihi'dir. Yirminci bab Fatih döneminin 1465 yılına kadarki olaylarını anlatırken Yirmi birinci bab Veziriazam Mahmud Paşa'nın gaza ve fetihlerini anlatmaktadır. Son yirmi ikinci bab ise Mahmud Paşaya medhiyedir. Bkz.(Özcan 1994:49-50; Öztürk 2012: XXX - XXXI). 


\section{din Mehmed El-Lârị̂ "Miratü’l-Edvâr" "Matrakçı Nasuh"11 "Mecma'u’t-Tevâ- rih"12,Gelibolulu Mustafa Ali13 "Künhü'l-Ahbâr"14,Bosnalı Hüseyin" "Be-}

9- Muslihiddin Lârî İran ( Lâristan) da doğmuş tarihçi ve müderristir. Mir Kemaleddin Hüseyin ve Mir Gıyas'dan ders almıştır. Hint İmparatoru Hümâyun Şah'a öğretmenlik yapmış Sultan'ın 1556 yılında vefatı üzerine önce Mekkeye giderek hacı olmuş sonra İstanbul'a gelerek Ebussuûd Efendiyle tanışmıştır. Bir süre sarayda görev yapmış ancak maaşının azlığına gücenerek Diyarbakır'a gitmiş Diyarbakır Valisi İskender Paşa tarafından Diyarbakır Hüsrev Paşa medrese müderrisliğine tayin edilmiştir. Lârî 1572 'de vefatına kadar Diyarbakır'da yaşamıştır. Mezarı Diyarbakır'da Safa camisinin güneybatısındaki Lârî medresesi yanındaki türbededir. Bkz. (Bayrak 2002: 260).

10- İranlı Molla Muslihiddin Lârî Farsça olarak 1566 y1lında Mir‘atül- Edvâr ve Mirkatü’l -Ahbar ( Haberlerin Derecesi ve Devirlerin Aynası ) adlı eserini telif etmiştir. Eser Hz. Ademden başlayarak Osmanlıların 1566 yılına kadarki olaylarını ve ünlü devlet adamlarını anlatmaktadır. Bkz. (Bayrak 2002: 260; Daş 2003: 137). Eser, Vezir Sokullu Mehmed Paşa'nın isteği ile Hoca Sadeddin tarafından genişletilerek Türkçeye çevrilmiştir. Hatta Hoca Sadeddin bu başarısı sayesinde Murat Paşa medresesinden Yıldırım Bayezıd Medresesine terfi ettirildiğini Tacü’t Tevarih'de kendisi ifade etmiştir. Bk. Daş, 2003:137. Ayrıca Hoca Sadeddin, Muslihiddin Lârî’nin eserini tercüme ederken özellikle eserin Osmanlı Tarihi kısmını yetersiz görmüş ve bu yüzden Tacü’t Tevarih'i telif etmeye başlamıştır. Bkz. (Aktepe 1958: 104).

11- Matrakçı Nasuh, matematik bilgini, ressam, hattat, tarihçi ve yazardır. Doğum yeri ve tarihi bilinmemektedir. Kendisinin bulduğu matrak oyunu nedeniyle Matrakçı olarak tanınmıştır. Bkz. (Bayrak 2002: 236; Yurdaydın 2003:143).

12- Mecma'u't-Tevârih (Tarihlerin Koleksiyonu) adlı eserin yazımına Kanunu Sultan Süleyman'ın emriyle Matrakçı tarafından 1520'de Taberî'nin Tarihu'l -Ümem ve'l-Mülûk adlı eserin Arapça'dan Türkçe'ye tercümesiyle başlanmış ve Matrakçının yaptığı ilavelerle 1551 yılına kadarki olaylara kadar getirilmiştir. Bu eserin birinci bölümü yaratılışdan Hz. Süleyman'ın ölümüne kadar olan dönemi içermektedir. İkinci bölüm İran Kralı Keykubad'ın hükümdarlığı ile başlayıp Sâsânî hükümdarı Nûşirevân devrine kadarki olayları anlatmaktadır. Üçüncü bölüm Hz. Muhammed'in doğumuyla başlayıp Abbasiler, Türklerin kökeni, Gazneliler, Selçuklular ve Osmanlıda Ertuğrul beyin Karacahisar'ı almasına kadar ki olayları içermektedir. Bkz.(Yurdayadın 2003:143; Davut 2005: XXVIII). Bu bitişle birlikte 1481 yılına kadarki olayları anlatan herhangi bir eser bulunmayıp bu zaman dilimi eksiktir. Dördüncü bölüm olarak düşünülen kısımla ilgili herhangi bir nüsha bulunmamaktadır. Bununla birlikte muhtasar olarak hazırlanmış eserler zinciriyle araştırmacılar tarafindan Mecma'üt-Tevârih'in parçalardan oluşan bir bütün olabileceği düşünülmektedir. Bu eserler zinciri şöyle sıralanabilir: Birincisi 14811520 tarihleri arasındaki olayları içeren Tarih-i Sultan Bâyezıd ve Sultan Selim adını taşıyan eserdir. İkincisi 1520-1537 yılı olaylarının anlatıldığı Matla-i Dasitan-1 Sultan Süleyman Han isimli eserdir. Üçüncüsü 1538 tarihli Feth-nâme-i Karabuğdan adlı eserdir. Dördüncüsü 1543 yılından başlayıp 1551 Kanuninin İstanbul'dan Edirne'ye gidişiyle son bulan eserdir. Bkz. (Davut 2011: 186-187; Yurdayadin 2003: 143-145).

13- Mustafa Ali 1541'de Gelibolu'da doğduğu için Gelibolulu Mustafa Ali olarak tanınmıştır. Defterdar, mutasarrıf, müderris, bilgin, tarihçi ve divan şairidir. Özel bir öğrenim görmüştür. 1566 yılında Sadrazam Ferhad Paşa'nın Divan Katibi, Defterdar, Yeniçeri Katibi ve Cidde mutasarrıfı olmuştur. Bu görevinde iken hacca gitmiş ve 1600 yılında Arabistan'ın Cidde kentinde vefat etmiştir. Bkz. (Kütükoğlu 1989: 414; Bayrak 2002: 154).

14- Künhü'l Ahbâr (Haberlerin Kaynağı) 1591-1599 yılları arasında sekiz yıllık bir süreçte telif edilmiştir. Eser rükün adı verilen dört bölüme ayrılmıştır. Birinci rükün Hz. Adem'den Hz. Yusuf'a kadar olan peygamberler ve hanedanları anlatmaktadır. İkinci rükün $\mathrm{Hz}$. İsa ve Hz. Muhammed'e kadar olan peygamberler tarihi ile İran ve Ptoleme hanedan tarihlerini içermektedir. Üçüncü rükün ise Emeviler ve Abbasiler dönemi ile Türk ve Moğol hanedan tarihleri hakkında bilgi vermektedir. Dördüncü rükün ise Osmanlı Devletinin başlangıcından III. Mehmed dönemi 1596 Eğri Seferine kadarki siyasi olaylar ile devlet adamları, şairler, âlimler hakkında uzun biyografileri içermektedir. Bkz. (Schmidt 2002: 555556; Kütükoğlu 1989: 415-416).

15- Bosnalı Hüseyin reisül-küttap, tarihçi ve yazardır. Bosna'da doğduğu için Bosnalı Hüseyin olarak anılmıştır. IV. Murad ile Bağdat Seferine katılmış ve gazi olmuştur. Ölüm tarihi kesin olarak bilinme- 


\section{dâiü'l-Vekayi""16, Kâtip Çelebi ${ }^{17}$ "Fezleketü'l-akvâli'l-ahyâr fi'ilmi’t-târîh ve'l-ahbâr” (Arapça Fezleke) ${ }^{18}$ / “Takvîmü’t-Tevârih” (Türkçe Fezleke ) ${ }^{19}$,Ka-}

mesine rağmen eserinde 1646 yılları olaylarına kadar bahsetmesi bu tarihte hayatta olduğuna delalet etmektedir. Bkz. (Bayrak 2002: 103; Özcan 2002: 130; Turp 2011: 1).

16- Bedâiü’1 Vekayi“ (Olayların Güzellikleri) iki ciltten oluşan eserin ne zaman yazıldığı tam olarak bilinmemekle birlikte eserde müellif 1645 'te birinci cildi temize çektiğini ve gördüğü rüya neticesinde ikinci cildi yazmaya karar verdiğini belirtmiştir. Birinci cilt kendi arasında beş fasıla ayrılmıştır. Birinci fasılda yer, gök, melekler, cinler, Hz. Adem ve Havva'nın yaratılışı, Hz. Muhammedin ecdadı, doğumu ve ölümüne ilişkin bilgiler yer almaktadır. İkinci fasılda Hülefâ-yi Raşidin, On İki İmam, Emevi, Abbasi ve Fatimiler anlatılmıştır. Üçüncü fasılda Horosan, Maveraünnehir Fars ve Azerbaycan'da saltanat süren devletler ile Mısır Şam ve diğer İslam ülkelerinin menkıbelerine yer verilmiştir. Dördüncü fasılda Cengiz Han ve İranlılardan bahsedilmiştir. Beşinci fasılda ise Samanoğulları, Gazneliler, Müslüman Afrika devletlerine ait bilgiler bulunmaktadır. Eserin İkinci cildi ise Osmanlının kuruluşundan Yavuz Sultan Selimin (1520) sonuna kadarki olayları ihtiva etmektedir. Bkz. (Özcan 2002:130-131; Turp 2011: 2-5).

17. Asıl adı Mustafa bin Abdullah'tır. 1609 yılında İstanbul'da doğmuştur. 1624 Tercan, 1629 Hamedan ve Bağdat, 1635 Revan savașlarına katılmıș ve buralarda ordu katipliği yapmıș, ulema arasında Kâtip Çelebi adını almıştır. Arapça, Farsça ve Latince bilen Katip Çelebi 1657 yılında İstanbul'da vefat etmiştir. Mezarı İstanbul Unkapanı'nda Atatürk Bulvarında Kapalıçarşı'nın bahçesindedir. Bkz. (Bayrak 2002: 204; Aycibin 2016: XXIX-XXXVIII).

18- Katip Çelebi'nin biyografik, coğrafi, tercüme, pratik, didaktik, matematik ve tarihi gibi alanlarda olmak üzere yirmiye yakın eseri vardır. Tarihi eserler başlığı altında yer alan ve umumi tarih olarak yazılan birinci eseri Fezleketü'l-akvâli'l-ahyâr fi'ilmi't-târîh ve'l-ahbâr' ( Haberler Tarihinde Erdemli Kişilerin Halleri Üzerine Özet ) dır. Dili Arapça olduğundan Arapça Fezleke olarak adlandırılan bu eserin telif tarihi 1642 'dir. Eserde yüz elli devlet ve bin beş yüz hükümdar hakkında bilgi vardır. Eser genel olarak bir mukaddime bir bölüm ve bir tetimme'den oluşmaktadır. Mukaddime bölümü de kendi arasında dört fasıla ayrılmıştır. Birinci fasıl eseri tanıtan genel bilgiler; ikinci fasıl tarihin manası, konusu ve faydaları; üçüncü fasıl esere kaynaklık eden eserlerin alfabetik sırası; dördüncü fasıl tarihçinin uyması gereken şartlar ve kuralları içerir. Birinci bölüm; yine kendi arasında fasıllara ayrılarak Yaratılış, Hz. Muhammed ve Dört Halife Devri, İslam öncesi hükümdarlar (Pers, Sâsânî, Yunan, Roma, Mısır, Benî İsrail, Hind, Çin, Türk, Süryani, Yemen, Benî Lahm, Gassanî, Kinde, Hicaz ), İslamiyet sonrası hükümdarlar, Osmanlılar ( Orhan Gazi'den Sultan İbrahim'e kadar siyasi olaylarla, sadrazamlar, şeyhülislamlar, kazaskerler, kadılar, padişah hocaları, nakibüleşrefler ve vezirler ) ve İslam tarihindeki zorba ve isyankar kişilerden ( Savcı Bey, Şeyh Bedreddin, Börklüce Mustafa, Mustafa Çelebi, Şah Kulu, Canberdi Gazâlî vb.) bahsetmektedir. Bkz. Aycibin 2016: V- VI, LIV-LVIII).

19- Katip Çelebi'nin ikinci umumi tarihi ise Takvîmü’t-Tevârîh (Tarihlerin Takvimi) adlı Arapça Fezleke'nin özet-fihrist mahiyetinde olan Türkçe Fezlekesidir. Eser 1649 yılında iki aylık bir çalışma sonucu yazılmıştır. Eser Genel olarak bir kitâbe, birçok levha, cetveller ve son kısımdaki hâtime ve hâtimetü'l-hâtime kısmından oluşmuştur. İçerik olarak genel hatlarla Yaratılıştan başlayarak tarihleri bilinen önemli kronolojik olayların sıralanması, İslam öncesi ile sonrası hükümdar sıralamaları ve Osmanlı döneminin 1648 yılına kadarki olaylarını içermektedir. Özellikle Osmanlı dönemi her padişaha ayrı cetveller ayrılarak sadrazamlar, şeyhülislamlar, kazaskerler, padişah hocaları, nakibüleşrefler, İstanbul kadıları, Mısır valileri, kaptan paşalar ve yeniçeri ağalarına ayrıntılı yer verilmiştir. Bkz.( Aycibin 2016: V- VI, LVIII-LVIII). 


\section{raçelebi-zâde Abdülaziz" "Ravzatü'l-Ebrâr"21, Müneccimbaşı Derviş Ahmed Dede $^{22}$ “Cami'ü’d-Düvel Sahâif’ül Ahbâr fi Vekayi'ül A'sar”"23, müellif-eser eş-}

20- Karaçelebi-zâde şeyhülislam, kazasker, kadı, müderris tarihçi ve divan şairidir. Babası Rumeli Kadıaskeri Hüsameddin Hüseyin Efendi'dir. 1591 yılında İstanbul'da doğmuştur. Yenişehir, Mekke ve İstanbul Kadılığı yapmıştır. 1648'de Rumeli Kazaskeri ve 1651'de Şeyhülislamlığa getirilmiştir. 1658 yılında Bursa'da vefat etmiştir. Mezarı Bursa'da Deveciler mezarlığında Akçalı Okul bahçesindedir. Bkz. (Bayrak 2002: 201-202; Özgül 2010: XI -XII).

21- Abdülaziz Efendi, Ravzatü’l Ebrâr (Geçmişteki Olaylar ve Haberler Işığında İyilerin Bahçesi) adlı eserini Rumeli Kadıaskeri olduğu yıllarda yazmaya başlayarak 1649 yılında tamamlayarak IV. Mehmed'e takdim etmiştir. Eser Hz.Adem'den başlayarak 1648 yılına kadar geçen olayları içermektedir. Dört fasıl ve iki tekmile olarak tertip edilmiştir. Birinci fasıl; peygamberlerin kıssa, vak'a ve bazı peygamber oğullarından bahsetmektedir. İkinci fasıl Hz. Muhammed'in hayatı ve savaşlarını anlatmaktadır. Üçüncü fasıl Dört halife ve İslâm hükümdarları ile İslâmiyet öncesi hükümdarların olaylarını içermektedir. Dördüncü fasıl ise Osmanlı Devleti'nin kuruluşundan Sultan IV. Mehmed'in cülûsuna (1058 / 1648) kadar Osmanlı Tarihini anlatır. Osmanlı tarihinin anlatıldığı dördüncü bölüm ise Osman Bey'den başlayarak her padişaha bir bölüm olmak üzere, kısımlara ayrılmıştır. Her kısmın sonunda padişahın doğumu, cülûsu, saltanat süresi, kaç yıl yaşadığı ve ölüm tarihleri, çocuklarının isim ve doğum ile ölüm tarihleri, vezir-i a'zamların isimleri vefat veya azil tarihleri ve şeyhülislâmların isimlerinden bahsetmektedir. Bkz. (Kaya 2001: 381-383; Özgül 2001: XLI -XLII).

22- Derviş Ahmed Dede; Mevlevi şeyhi, müneccimbaşı, besteci, tarihçi, yazar ve şairdir. 1631 yılında Selanik’te doğmuștur. Selanik Mevlevi Tekkesinde eğitim almıș ve 1656 yılında İstanbul'a gelerek İbrahim Gerdi, Ahmed Nahli Efendi, Şeyh Halil Dede, Salih Efendi ve Müneccimbaş1 Mehmed Efendi gibi ünlü kişilerden ders almıştır. Müneccimbaşı Mehmed Efendi vefat edince onun yerine Müneccimbaşılığına atanmıştır. 1691'de hac ziyaretini yapmış ve Mekke Şeyhliği yapmıştır. 1694-1700 tarihleri arasında Medine'de hadis, tefsir ve fikıh dersleri vermiştir. 1700 yılında tekrar Mekke'ye dönmüş ve 1702 tarihinde Mekke'de vefat etmiştir. Mezarı Mekke'de Mevlevî mezarlığındadır. Bkz. (Bayrak 2002: 265; Ağırakça 2006: 4).

23- Cami‘ü’d-Düvel ( Yüzyılların Olayları Hakkında Haber Sayfaları ve Bütün Devletler ); Sadrazam Kara Mustafa Paşa'nın emriyle Arapça olarak yazılmıştır. İçerik olarak yaratılıştan 1670 yılına kadarki olayları içerir. Eser meşhur tarihçilerin anlatıldığ 1 bir mukaddime ve iki ciltten oluşmuştur. Birinci Ciltte Hz. Adem'den Hz. Muhammed'e kadar bütün peygamberlerin hayat hikâyeleri, Hz. İsa ve İslâm öncesi Arabistan'ın durumu, Kureyş kabilesinin aslı ve Mekke tarihi, Hz. Muhammed'in doğumu, Hz. Peygamber'in şemâili, ashabı, zevceleri, Dört Halife devri, Süryaniler, Gassaniler, İranlılar, Yunanlılar, Amalika, Kıptîler, Hindular, Türk ve Tatarlar, Türkmen kabileleri, Çinliler, Bulgarlar, Ruslar ve Gürcüler'den bahsedilir. Ardından Batı'ya geçilerek Franklar, İngilizler, İspanyollar, bu arada Karadeniz, Akdeniz, Hint Okyanusu, Adriyatik denizi hakkında bilgi verilir. Daha sonra tekrar daha ayrıntılı olarak İran, Sâsânîler ve Mezopotamya'da eski Arap kabilelerinden ve tekrar Gassanilerden söz eder. Daha sonra yine Batı dünyasına geçilerek Romalılar, Almanlar ve İspanyollar anlatılır. Ardından Mısır, Hint, Çin, Emevi, Endülüs Emeviler, Abbasiler, Ağlabiler, Tahiriler, Samaniler, Kirman, Cürcan, Harezm, Gazneliler, Tolunoğulları, Hemdaniler, İşhidoğulları, Rüstemoğulları, İdrisoğulları, Deylemiler, Saffariler, Fatimiler, Büveyhoğulları, Büyük Selçuklular, Kirman Selçukluları, Suriye Selçukluları, Türkiye Selçukluları, Danişmendler, Artuklular, Musul ve Şam Atabeglikleri, Horosan Emirleri, Harzemşahlar, Karahitaylar, Kuzey Afrika'da Mülsemiler ve Muvahhidler yer alır. Görüldüğü gibi Birinci Ciltte kronolojik sıra takip edilmeden devletler karışık olarak verilmiştir. İkinci Ciltte ise Kuzey Afrika'daki küçük emirliklerle Eyyübiler, Moğollar, Karamanoğulları, İsfendiyaroğulları, Aydınoğulları, Menteşeoğulları, Germiyanoğulları, Hamidoğulları, Karesioğulları, Canik Beyliği, Varsaklar, Kadı Burhaneddin, Timur, Karakoyunlular, Akkoyunlular, Dulkadiroğulları, Ramazanoğulları ve Osmanlı Devletinden bahseder. Osmanlı Devleti tarihi ve özellikle müellifin kendi devri olan IV. Mehmed dönemi için yazılanlar oldukça önemlidir. Bkz. (Ağırakça 2006: 4-6; Ağırakça 2014: 28-32.; Ünlü 1990: XXVIII- XXXII; Tellioğlu 1994: 14-17). Ayrıca Müneccimbaş1 Derviş Ahmed eserinin başında tarih ilmi, faydaları ve tarihçilerde bulunması gereken vasıflardan da bahsetmiștir. Bu konularda Taceddin es-Sübkî'nin "Tabakâtüş-Şafiiye" adlı eserindeki görüşlerini paylaşmakta ve tarih ilminin tanımlama- 
leştirmelerinde görmek mümkündür. Çalışmanın konusu muhtasar umumi tarihlerin anlatım tarzı üzerine analiz olduğundan mufassal umumi tarihlerin içerik örneklerine yer verilmemiştir.

\subsection{Muhtasar Umumi Tarihler}

Muhtasar kelimesi mana olarak “Az, kısa, uzun olmayan, tekellüfsüz, ihtisar edilmiş, kısaltılmış" anlamlarına gelmektedir. Bu tanımdan da anlaşılacağı üzere bu gruba giren umumi tarihlerde içerikler oldukça kısa bir şekilde hülasa olarak tasvirlenmiştir. Bu grubun içeriklerine ait özet anlatım örnekleri müellif-eser eşleştirmeleri üzerinden şu şekildedir.

\subsubsection{Mevlana Şükrullah "Behçetü’t-Tevârih"}

Şükrullah'1n hangi tarihte ve nerede doğduğu tam olarak bilinmemektedir. Eserinden edinilen bilgilere göre 1409 tarihinde 22 yaşında iken saray hizmetine girmiştir. II. Murad döneminde elçi olarak Karamanoğullarına ve Karakoyunlulara gönderilmiştir. Kesin olmamakla birlikte ölüm tarihi 1464 olarak tahmin edilmektedir (Bayrak 2002: 340-341; Almaz 2013: 24-29).

Behçetü’t-Tevârih adlı eser Sadrazam Mahmud Paşa'ya ithafen 14561459 yılları arasında Farsça olarak yazılmıştır. İçerik olarak eserini yazarken yararlandığı kaynakların anlatıldığ kadar olayların anlatıldığg On üç bölümden oluşmuştur (Yıldız 2010: 257).

Birinci bölüm İnsanın yaratılmasından önce akı1, nefis, yıldız, doğa ateş, hava, su ve toprağın yaratılması, yedi iklim ve yedi denizin, yerleşim yerlerindeki Çin, Türk, Rum, Arap, Hint, Habeşilerden, Hz. Âdem ve insanlık tarihi ile ilgili bilgilerden oluşmuştur. İkinci bölüm Kur’an ‘da adı geçen Peygamberlerin Tarihini içermektedir. Üçüncü bölüm Hz. Muhammed'in Hz Adem'e kadar inen nesebine kadar bilgi vermektedir. Dördüncü bölüm Hz. Muhammed'in doğumu, önemli olayları, savaşları, mucizelerini anlatmaktadır. Beşinci bölüm Hz. Muhammed'in eşleri, cariyeleri, evlatları, amcaları, halalarına ait bilgiler vermektedir. Altıncı bölüm Aşere-i Mübeşşere, Yedinci bölüm diğer önemli sahabeler, Sekizinci bölüm Dört mezheb imamı, altı hadis imamı, ve İslam alimleri tarafından fetvaları kabul gören sekiz imam hakkında bilgi vermektedir. Dokuzuncu

sını, faydalarını ve tarihçilerde bulunması gereken vasıfları ayrıntılı şekilde anlatmaktadır. Özellikle bir tarihçide bulunması gereken en önemli ilkelerin tarafsızlık ve yorum gücü olduğunu belirtmiştir. Ve bir tarihçinin aynı dine ve inanca sahip olmadığı kişilere de itibar etmemesi gerektiğini düşünmektedir. Bkz. (Akbulut 2006; 84-87). 
bölüm yüz yedi meşhur tarikat şeyhi, Onuncu bölüm Yunan ve diğer dinlerdeki önemli filozofları anlatmaktadır. On birinci bölüm İran Padişahları, Keyler, Eşkâniler, Sâsânilere ait bilgiler sunmaktadır. Onikinci bölüm Emevi, Abbasi, Alevî ve Selçuklu Sultanları, Onüçüncü bölüm ise Osmanlı devletinin kuruluşu ve Fatih Sultan Mehmed'e kadar gelen padişahların hayatı önemli olayları ve hayratları anlatılmıştır (Almaz 2013: 38-40).

Şükrullah eserini kısa-özet şeklinde yazdığını metin içinde " Hz. Peygamberin vefatından Behcetü't-Tevârîh adlı bu özet eserin kaleme alınışına kadar 849 yıl olub Osmanoğullarından, gaziler sultanı Mehmed b. Murad Han 'ın tahta oturuşunun sekizinci yılıdır." şeklinde ifade etmiştir. (Almaz, 2013: 37) Yine eserini kısa özet şeklinde yazmasının nedeni olarak Sultan Murad döneminde yapılan hayratların çokluğundan bahsederken, bunların teker teker yazması halinde amacından sapacağı endişesiyle kısa yazdığını "Halil-i Çandarî ve diğer birkaçının dediği gibi ĕger bunların tümünü teker teker yazacak olursak söz uzar ve maksadımızdan uzak kalmış oluruz." cümlesiyle anlatmıştır (Almaz 2013: 382).

Eserde Osmanlı Tarihindeki belirli olayların kısa-özet olarak anlatılmasına metinden şu örnekleri verebilir:

Osman Bey'in devletin başına geçmesi kısa olarak "Emir Osman'a sancak, kaftan ve davul ulaşınca ayağa kalktı. Davulu padişahlı̆̆a uygun olarak çalıp tebrik ettiler. O zamandan beri Osman'in bir adeti olarak Osmanlılar savaşa çıktıklarında davula vurulunca ayağa kalkılır.” (Almaz 2013: 379). şeklinde anlatılmıştır.

Osman Bey tarafından Bileciğ' in alınmasını "Emir Osman İslam ordusunu topladı. Bir kısmı kendi beraberinde Bilecik'e yerleşti. Bir kısmı da diğer kâfir vilayetlerine gönderildi. Birçok ölüm ve yağmalar yaptılar. Kâfirler yenilgiye uğradı. Bilecik fethedildi. Emir Osman Bilecik'i 664 yılında fethetti." (Almaz 2013: 379) cümleleriyle aktarmıştır.

Orhan Beyin padişah olması ve dönemindeki fetihler hülasa olarak “ Orhan Bey padişah olunca din bayră̆l daha belirgin hale geldi, kâfirlerin yönetimi ise düşüşe geçti. Küfrün parlakliğl kalmad, hatta yok oldu. İslam ehlinin yükselişi arttı. Ordu her bir tarafa gidiyor ve sayısı ganimet ve esir getiriyordu. Az bir zaman geçtikten sonra Ulubat ve Bursayl fethetti. Ondan sonra büyük çabalar harcadl ve İzik'i de fethetti. " (Almaz, 2013: 380) cümleleriyle belirtmiştir. 
II. Murad dönemi fetihleri de sadece isimleri verilerek "Beş savaş yaptı. Birincisi Selanik fethedildi. İkincisi Derbendizledi savaşı, üçüncüsü Varna Savaşı, dördüncüsü Germe savaşı beşincisi de Kosova savaşıdır.” (Almaz 2013: 392) başlık şeklinde yazılmıştır.

\subsubsection{Ramazân-zâde Nişâncı Mehmed Paşa "Târîh-i Nişâncı Paşa"}

XVI. yüzyılda yaşamış Nişâncı Mehmed Paşa Kanuni Sultan Süleyman dönemi devlet adamı ve tarihçisidir. Müellifin doğum tarihi hakkında arşivlerde ve kaynaklarda herhangi bir bilgiye ulaşılamamıştır.

Nişâncı Mehmed Paşa'nın ilk yıllarına ait herhangi bir bilgi mevcut olmamakla birlikte Merzifonlu olduğu bilinmektedir ${ }^{24}$ (Tahir 1975: 119). Mekke, Mısır ve Medine kadılığı yapmış Ahmed Efendi'nin babasıdır. Ayrıca XVII. yüzyıl tarihçilerinden Mir'at-1 Kâ'inât adlı eserin sahibi Mekke, Medine, Misır, Selânik, Bursa ve İstanbul kadılıkları da yapan Mehmed Kudsî’nin dedesidir ${ }^{25}$ (Bayrak 2002: 296; Özcan 2003: 450).

Ramazân-zâde medrese talebeliği sırasında "Yeşilce" lakabıyla tanınmıştır ( Özcan 2003: 449). Çağdaş ve meslektaşı olan ünlü nişâncı ve tarihçi Celâl-zâde Mustafa Çelebi'den ayırt edilebilmesi için "Küçük Nişâncı” unvanıyla şöhret bulmuştur (Bayrak 2002: 280). Babasından dolayı ise "Ramazân-zâde" olarak anılmıştır ${ }^{26}$ (Arslan 2003: 42; Resmi Efendi 1269:7).

Müellif medrese tahsilinden sonra sırasıyla Divanıhümayun kâtibi ve $\mathrm{H}$ 960 / M 1553 yılında başdefterdar olmuştur. Ramazân-zâde Mehmed Paşa H

24- Mehmed Cemâleddîn, Osmanlı Tarih ve Müverrihleri-Âyine-i Zurefâ adlı eserinde Merzifonlu olduğu bilgisini "Müşârü'n-ileyh, Anatolu'da Merzîfon kazâsında bedîdâr olup". şeklinde vermiştir. Bk. Arslan, 2003: 42 ; Ahmed Resmi Efendi, Halifetü'r-Rüesâ adlı eserinde ise aynı bilgiyi "Vilâyet-i Anatolu'da Merzîfondan pedîdâr". şeklinde vermiştir. Bkz. (Resmi Efendi 1269: 7)

25- Mehmed Cemâleddîn, Osmanlı Tarih ve Müverrihleri-Âyine-i Zurefâ adlı eserinde " "Âșir-i selâtîn-i Âl-i 'Osmân Sultân Süleymân Hân hazretlerinin zâman-1 ma'delet-nişânlarında nişâncılık mansıb-1 celili ile magbûtü'l-akrân ve te'lîf-kerdesi bulunan "Târîh-i Muhtasar" 1 şöhret-gîr-i cihân olan tercemesi sebkat eyleyen Ramazân-zâde Mehmed Beyefendi'nin ferzend-i ercemedndî olup, toḳuz yüz altmış üç (1555) senesi cimâde'l-ûlâsında târîk-i feyz-refík-i 'ulemâya bâ-rütbe-i hâric dâhil ve toḳuz yetmiş bir ( 1563) cümâde'l-âhirinde Mekke-i Mükerrreme mevleviyyetine nâ'il ve toḳuz yüz yetmiş dört ( 1566) şehr-i rebî’ül-âhirinde kazâ-i Mısr'a ve toḳuz yüz seksen altı (1578) senesinde Medîne-i Münevvere mevleviyyetine vâsıl olup sene-i mezbûre saferü'l-hayrında Şâm-1 Şerîf'e iki merhale karîb mahalde menzil-i vücûddan rıhlet ve mahmil-bend-i 'âlem-i âhiret oldıḳda, cenâzesi Şâm-1 Şerîf'e bi'n-nakl mekâbir-i sâlihînde medfûn ve 'âlim ü fâzıll-1 zâ-fünûn, sâhibü'l-âsâr-1 'ârîf-i nâm-dâr Ahmed Efendi'nin pûr-1 pür-nûru Mehmed Efendi' dir ki "şeklinde tanıtmıştır. Bkz. (Arslan 2003: 42).

26- Mehmed Cemâleddîn'in Osmanlı Tarih ve Müverrihleri-Âyine-i Zurefâ adlı eseri ile Ahmed Resmi Efendi' Halifetü'r-Rüesâ adlı eserinde "Ramazân-zâde demekle iştihâr ve mâh-1 rûze gibi kadr ü 'itibâr bulmuş idi." şeklinde görülmektedir. Bkz. (Arslan 2003: 42; Resmi Efendi 1269: 7). 
961 / M 1554 yılında reisülküttaplık (Süreyya 1996: 968) ardından Mora vilayeti toprak yazımını yapmıştır. Bu görevindeki başarısından dolayı kendisine nişancılık vazifesi verilmiştir (Baykal 1999: 47). İlk nişancılık görevinin verilmesine tarih olarak H 965 / M 1557-1558 yılı kabul edilmektedir ${ }^{27}$ (Süreyya 1996: 968). Nişancılık payesinin verilmesinin ardından Ramazân-zâde'ye "Paşa" ve “Tevkî' denilmeye başlanmıştır'28 (Özcan 2003: 450).

Ramazân-zâde nişancılık görevini ifâ ettikten bir müddet sonra muhtemelen rakiplerinin oyunuyla önce defter eminliğine atanmıştır. Ardından merkezi Halep'te olan Arap-Acem defterdarlığına ve oradan da Mısır'a sancak beyi olarak gönderilmiştir ${ }^{29}$ (Özcan 2003: 450).

Nişâncı Mehmed Paşa'nın Mısır'a sancak beyi olarak gönderilmesi sırasında nişancılık görevinin boşalması üzerine Kanuni Sultan Süleyman nişanc1lık makamı için Ramazân-zâde'nin Mısır'dan getirilmesini emretmiştir. Fakat Ramazân-zâde'ye muhalif olan sadrazam Rüstem Paşa, padişaha Ramazân-zâde'nin kendi isteğiyle Misır'a gittiğini belirtince, ${ }^{30}$ Kanuni Sultan Süleyman sadrazamın cevabını hiçe sayarak, ${ }^{31}$ Ramazân-zâde'yi İstanbul'a çağırtmış ve H 969 / M 1562 yılında ikinci defa nişancılığa getirmiştir. ${ }^{32}$ Ancak bir süre sonra müellif H 970 / M 1562'de 50.000 akçelik zeametle emekli olmuştur. ${ }^{33}$

27- Mehmed Cemâleddîn, Osmanlı Tarih ve Müverrihleri-Âyine-i Zurefâ adlı eserinde "Toḳuz yüz altmış beş (1557) senesinde tugrâ-keş-i dîvân-1 sultânî ve müftî-i müskil-güşâ-yı kânun-1 'Osmânî oldu." şeklinde vermiştir. Bkz. (Arslan 2003: 42) Ve Nev‘î-zâde Atâyî Zeyl-i Şakâ’ik adlı eserinde Kanuni Sultan Süleyman dönemi nişâncılar ismini zikrederken Ramazân-zâde’yi “ Ramazân-zâde: Fî sene 965.” şeklinde tanıtmıştır. Bkz. (Donuk 2017: 476) Yine 965 tarihini Ahmed Resmi Efendi’ Halifetü’r-Rüesâ adlı eserinde "Mora vilâyetini tahrire mâmuretinden sonra toḳuz yüz altmış beş senesinde nişâncılık rütbesine vâsıl" şeklinde görmek mümkündür. Bkz.( Resmi Efendi 1269: 7).

28- ̇̉brahim Peçevî Efendi Ramazân-zâde için "Tevkî‘ Ramazân-zâde" ibaresini kullanmıştır. Bkz. (Peçevi 1269: 2).

29- “'Ramazân-zâde Mehmed Çelebi zümre-i 'ulemâ'dan iken tarîk-i kitâbiyete sâlik olub, kâh defter emini kâh re'îs olub sonra Mora vilâyetini tâhrîr idüb, nişânc1 rütbesine vâsıl olmuş sonra yine defter emîni olub andan 'Arab ve 'Acem Defter-dârı itmişler. Ba'dehû 'azl olınub Mısır muhâfazası sancağı virilmiş. ...” Bkz. (Peçevi 1269: 44.

30- "sadr-1 a'zam âhre murâd idinmekle”, Bkz.(Peçevi, 1269: 44).

31- "hazret-i padişah kadir şinâs cevaba iltifât itmeyüb "ehil olanlar kapumuzdan Mısır'a gönderilmek ne revâdır. Belki Mısır'dan ve gayri diyârdan anın gibi âdemleri Âsitânemize getürülmek sezâdır." diyü buyrulmağla Mısır'dan gelüb nice yıllar tûğrây-1 'azâ hizmetinde olmışdır ”. Bkz. (Peçevi 1269: 44).

32- "ba‘d-ı zaman nişâncılık mahlûl oldıḳda Mora yazımını yapan Mehmed'e verdim." Bkz.(Peçevi 1269:44).

33- Mehmed Cemâleddîn, Osmanlı Tarih ve Müverrihleri-Âyine-i Zurefâ adlı eserinde "Toḳuz yetmiş (1562) //28// senesi hitâmında elli bin akçe ze âmetle mütekâ'id olup," şeklinde vermiştir. Bk. Arslan, 2003:42 ; Ve Nev'î-zâde Atâyî Zeyl-i Şakâ'ik adlı eserinde "toḳuz yüz yetmiş temâmında halefi Ramazân-zâde yirine mansıb-1 tuğraya i'âde olınıp (970) [ التكرار حسن ] târîh vâki' oldı." şeklinde vermiş- 
Müellifin ölüm tarihi hakkında tam bir görüş birliğine varılamamıştır. Peçevî İbrahim Efendi eserinde Ramazân-zâde'nin ölüm tarihine ilişkin herhangi bir bilgi vermezken, ${ }^{34}$ kabul gören ortak görüş Ramazân-zâde'nin Fatih semtindeki evinde H 979 Cemaziyelevvel (Ekim 1571) tarihinde öldüğüdür ${ }^{35}$ (Özcan 2003: 450). Ramazan-zâde'nin mezarı İstanbul' da Edirnekapı sur dışındaki Emîr Buhârî Tekkesi haziresinde iken daha sonraları açılan çevre yolu nedeniyle yıkılmıştır (Bayrak 2002: 296).

Târîh-i Nişâncı Paşa adlı eser dört bölümden oluşmuştur. Birinci bölüm Hz.Adem'den Hz. Muhammed'e kadar bir peygamberler tarihidir. Müellif bu bölümde peygamberlere dair kıssalara da yer verilmiştir. İkinci bölümde Asr-1 saâdet, Hulefâ-i Râşidîn, Emevîler, Abbasiler, Fatimiler, Eyyûbîler ve Memlükler ve Çerkez Devletinin Halife ve hükümdarlarının doğum ve saltanatları hakkında bilgiler ile dönemlerin ilim adamlarından da bahsedilmektedir. Üçüncü bölüm eserin büyük bir bölümünü oluşturarak Osmanlılara ayrılmıştır. Bu bölümün büyük kısmını ise Kanuni dönemi olayları oluşturmaktadır. Osmanlı Tarihi bölümünde her padişahın doğum, ölüm, çocukları vezirleri, gazaları, hayrat ve hasenatları ile dönemin ulemâ, meşâyih, devlet adamları ve bunların eserlerinden kısaca söz edilmektedir. Özellikle II.Bayezıd ve Kanuni Sultan Süleyman dönemlerinde muhtasarlık içinde kısmi mufasallıkla olayların ayrıntılandığı k1sım olmuştur. Bu bölüm siyasi olarak Kanuni'nin oğlu Bayezid'in Kazvin'de öldürülmesi ile son bulmaktadır. Dördüncü bölümde ise müellif diğer devletler diye adlandırabileceğimiz Tevârîh-i Şâhân-1 Pîşîn ve Mülûk-i Âdile-i Mukaddimîn başlığg altında Kayser, Kisrâ, Keyâniler, Eşkâniyanlar, Sâsâniler, Batlamyuslar, Yunanlılar ve Roma imparatorluğunun özet şeklinde hükümdarlarından bahsetmektedir. (Ramazân-zâde, Târîh-i Nişâncı Paşa [yz.] Almanya Staatsbibliothek, Berlin, Ms.or.fol.4153, Vr. 1 ${ }^{\mathrm{b}}-134^{\mathrm{b}}$. )

Ramazan-zâde eserini tıpkı Şükrullah gibi kısa özet şeklinde yazmış ve bunu eserin giriş kısmında "Lâkin kütüb-i tevârîhde olan cerâ'id-i fevâ'idiñ ekserî kesîretü'l-cennete kesîretü'l-kıssa olub muktezîli itâlet ve melâl-i

tir. Bkz. (Donuk 2017: 369).

34- "Sonra mütekâ'id olub evkât-1 hamseyi Sultan Mehemmed Han câmi'-i şerîfinde kılurlardı. Bu halde iken cevâr rahmete intikâl itdiler. Bir muhtasar târihi tahrîr itmişlerdir. El-hak hûb vâki ‘ olmış ve kemâl-i mertebe şöhret bulmuşdur". Bkz. (Peçevi 1269: 44).

35- Mehmed Cemâleddîn, Osmanlı Tarih ve Müverrihleri-Âyine-i Zurefầ adlı eserinde "toḳuz yetmiş toḳuz cümâde'l-ûlâsında dâr-1 bekâya rıhlet eylemişdir. Rahimehullâh." şeklinde vermiștir. Bk. Arslan, 2003: 42; Katip Çelebi'nin Keşfü'z-zunûn adlı eserinde “ Târihû Ramadân-zâde Muhammed etTevkî‘iyy (Nişâncı Ramadân-zâde Muhammed'in Tarih Kitâbı): Bu zât doḳuz yüz yetmiş doḳuz yılında ölmüştür (979H) ve bu kitâp Türkçedir, kısadır.” şeklinde tanıtılmıştır. Bkz. (Balc1 2007: 275). 
muktezîi-i kesâlet ü kelâl olmaġın"36 cümlesiyle ifade etmiştir. (Ramazân-zâde, Târîh-i Nişâncı Paşa [yz.] Almanya Staatsbibliothek, Berlin, Ms.or.fol.4153, Vr. $3^{\text {a }}$.) Bu nedenle eser kısa-hülasa-özet olarak bir el-kitabı olarak oluşturmuştur.

Eserde içeriğin kısa-özet olarak anlatılmasına Osmanlı tarihindeki belirli olaylar üzerinden şu örnekler verilebilir:

Osman Bey'in tahta geçişi kısa olarak “Kara Hisâr feth olunıb içinde Cum 'a nemâzı ḳlınub 'Osmân Ġāzî kırk üç yaşında kendi adına ibtidâ hutbe Tursun Fakîh nâm ehl-i 'ilm oḳudl. Fî sene 699.” şeklinde anlatılmıştır. (Ramazân-zâde, Târîh-i Nişâncı Paşa [yz.] Almanya Staatsbibliothek, Berlin, Ms.or.fol.4153, Vr. 43a.)

Bursa'nın alınmas1 "Feth-i Kal'a-i Bursa. Fî sene 722 . [1322 / 1323] Mahrûse-i mezbûre gāyet sa'ab hisâr olub Kapluca cânibinde şehre havâle Müselmânlar bir ḳulle yapub ba'zı âdemlerle 'Osmân Ġāzî karındaşı og்lı Ak-Timur nâm bahâdırı anda koyub ve tag tarafinda dahî bir havâle [olınan] kulle yapub ba'zı kimesne ile kulı Balabancık nâm bahâdırı anda koyub nâhiyesinde olan köyler zabt olınub taşra âdem çıkartmaz oldılar. Kal'a halkı açlıkdan zebûn olub Şehzâde Orhân Hân'a kal'a ve şehri teslîm etdiler." şeklinde ifade edilmiştir. (Ramazân-zâde, Târîh-i Nişânc1 Paşa [yz.] Almanya Staatsbibliothek, Berlin, Ms.or.fol.4153, Vr. 44a.)

Sultan Murad Gazi döneminde Edirne'nin fethi hülasa biçimde "Edirne : Feth-i Kal'a-i Mahrûse-i Edirne. Mukaddemâ Lâlâ Şahin Edirne fethine 'askerle gönderildikde Edirne tekfûrı çıkub 'askeri karşulayub 'azîm ceng ü kıtâl olub kâfirler âhir münhezim olub kal'aya girüb Sultân Murâd Hân kal 'a üzerine gelicek Meric taşg்n olmaġın tekfûr sandala binüb kaçub kal'a hâlî ḳalmaġın ehl-i İslâm zabt etdi . Fî sene 761." cümleleriyle aktarılmıştır. (Ramazân-zâde, Târîh-i Nişâncı Paşa [yz.] Almanya Staatsbibliothek, Berlin, Ms.or.fol.4153, Vr. 48 b.)

Fatih Sultan Mehmed'in İstanbul'u feth etmesi "Feth-i Kal 'a-i Kostantiniyye. Fî̀yevmü'l-erba'a fî 20 Cemâziye'l-âhir fî sene 857. Sultân Mehemmed $\dot{G} \bar{a} z \bar{l}$ dört yüz pâre gemi tonadıb deryâ tarafindan ve yetmiş pâre gemi Galata üstünden yelken açub ḳurıdan çekdirib Hazret-i Eyyûb Ensârî civârında olan deryâya getürüb üzerinde köpri yapulıb 'asker geçürüb elli gün mikdârı kal'a cengin idüb elli birinci gün Çeharşenbe güninde ḳal'a[yl] feth eyleyüb 'asker-i

36- cümlesiyle meâlen "kolay saklamak, can sıkmayan, yorgunluk vermeyen şekilde izah etmek" 
İslâm mâl-ı ganîmete müstagrik oldılar. Ayasofya'da Cum 'a namâzı ḳılındı . Fî sene 857. . ” özet olarak yapılan hazırlıklar ve sonuç odaklı olarak anlatılmıştır. (Ramazân-zâde, Târîh-i Nişâncı Paşa [yz.] Almanya Staatsbibliothek, Berlin, Ms.or.fol.4153, Vr. 66 .)

Yavuz Sultan dönemindeki Mercidabık Savaşı hülasa olarak "Hazret-i fâtih-i memâlik-i 'Arab u 'Acem vâris-i memleket-i dârâ vü cem yümn-i ikbâlle 'Acem seferine gider iken Sultân-ı Mısır arḳurl yoluna geldi. Sultân-ı Misır Kansu Gavri'niñ devr-i cevr-i âhire yetişmek mukadder imiş ki pür-sâz ve selb-i tâ'ife-i Haleb ve Çerkes nâkeslariyle hâzır olub berü cânibince nâzır oldl. Haleb kurbında Mercidabık nâm mahalde ceng-i 'azîm olub Kansu Ġavri ol-cenkde hâk-i helâki düşdi. Fî sene 922.” şeklinde ifade edilmiştir. (Ramazân-zâde, Târîh-i Nişâncı Paşa [yz.] Almanya Staatsbibliothek, Berlin, Ms.or.fol.4153, Vr. 83 .)

Kanuni Sultan Süleyman döneminde Belgrad'ın alınması "Feth-i Kal 'a-i Belgrad-i Sengîn-Bünyâd. Fî 26 Ramazân. Fi sene 927: Kal'a-i zâtü'l-burûc var. Bir hisâr-l sevâbit karârdır ki me 'âric-i medâric 'urûcı kehkeşâne vülûc etmişdir. Şimdiye degin kemend-i feth ü recâ küngüre-i kâh-ı kibriyâsına atılmamışdır. 'Asker-i zafer-eser havâli kal 'ada hâlî yir ḳomıyub aña hâttü'l-etvâk. bi'l-'anâk hisâr-l mezbûr mahsûr olub yir yir toplar kurllub odlar virilüb dûd-i şerâr âlûdi 'ayyûka su' ûd etdükde gûyâ ol-kavm-i dâllin üzre zelzele-i kıyâmet kopard. Ve mukātele-i ceng-i 'azîmden soñra bi-hamdi'llahi'l-mülkü'l-ekber çehre-i feth ü zafer âyîne-i tîg u teber leşker-i nusret eserde cilveger oldı." şeklinde kalenin özellikleri, önemi, yapılan hazırlıklar ve sonuç kısa olarak anlatılmıştır. (Ramazân-zâde, Târîh-i Nişâncı Paşa [yz.] Almanya Staatsbibliothek, Berlin, Ms.or.fol.4153, Vr. 97a . )

Kanuni dönemi Rodos'un alınmas1 “Feth-i Kal 'a-i Rodos. Fî 6 Safer . Fî sene 929. Cezîre-i deryâda bir sahrâ-yı hadrâda bir hisâr-ı âhenîn dîvârdır ki pence-i bârûsî girîbân-l âsmâne hem-ser belki menzil-i hevte berâber ve delvden güzer ider. Hendek-i 'amîkine im 'ân-ı nazar-ı dakīk ile ihâta müyesser ü mütesavver olmıyub gavvâs ve hem seyyâh-ı fehm-i pâyânîdir. Kende-i hayrân ve sergerdânlardır. Bi'l-cümle bünyân-ı cüdrânı ka 'r-l âbide kelle-i kullesi çeşme-i âfitâbda a'dâ-yı dîniñ ol-ḳal'a-i metîn-i deryâda mâhî gibi neşîmen ve ârâm-gâhî olub dâm-ı in 'idâm sayyâd-ı ehl-i İslâm'dan melce-i girîz-gâh ve mâmin ve penâhları imiş. Ol-hisâr-l felek-medâra istîlâ ve isti 'la nakş-ı rekm-i 'âle'l-mâ-i gibi hâric-i endîşe-i 'ukalâ olmag̀ın selâtîn-i mütekaddimîn bahr-i 


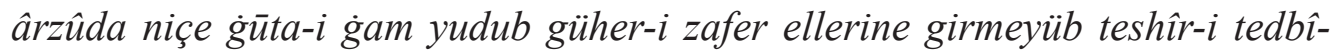
rinde garîk-i bihâr-l efkâr olmışlar idi. Hazret-i pâdişâh-ı deryâ-dil 'asâkir-i düşman-ı kesel ile sefâ'in-i zafer-i defâ'ine binüb bi'z-zât cezîreye nüzûl ü iclâl idüb fi'l-hâl tehnîye-i âlât-l cidâl ü cenk 'ale'l-ittisâl toblar ve prankiler ve darbezenler atılub tob u tüfenk darbından ve zenberiñ a'dâ-yı bedrâyıñ başına yagmur gibi yagdirlld. Bi-hamdi'llahi'l-mülkü'l-ekber feth ü nusret müyesser olub kal 'a içine girülüb zabt olındı." şeklinde fethin gerekçeleri, yapılan hazırlıklar ve sonuç odaklı olarak özetlenmiştir. (Ramazân-zâde, Târîh-i Nişâncî Paşa [yz.] Almanya Staatsbibliothek, Berlin, Ms.or.fol.4153, Vr. 97º 98a.)

\subsubsection{Cenâbî Mustafa Efendi “El-Aylemü’z-Zahir” veya “Gülşen-i Tevârîh"}

Cenâbî müderris, kadı, tarihçi ve divan şairidir. Niksarlı Emir Hasan Efendinin oğludur. Edirne'de eğitim görmüş ve İstanbul'da Ebussuud Efendi'den dahi ders almıştır. Çeşitli tarihlerde İstanbul, Bursa ve Edirne'de müderrislik yapmış ve 1586 yılında Halep kadısı olmuş ve bu görevi sürdürürken 1590 y1lında vefat etmiştir (Bayrak 2002: 261).

Cenâbî'nin el-Aylemü'z-zahir fi Ahvâl'il evâli ve'l evâhir adlı eser Cenâbî Tarihi olarak da bilinmektedir. Eser 1587 yılında tamamlanarak III. Murada takdim edilmiştir. Osmanlı Tarihinin anlatıldığı kısım 1589 yılına kadarki olayları ihtiva etmekle birlikte eserin büyük bir kısmını oluşturmaktadır ( Canatar, 1993: 351-352).

Eser içerik olarak bir Mukaddime, seksenaltı bölümden oluşmaktadır. Bu bölümler Peygamberler Tarihi, İslam Öncesi Devlet ve Kavimler, Hz. Muhammed ve Hulafa-yı Raşidin, Şam ve Endülüs Emevileri, Abbasiler, İdrisiler, A $\breve{g}$ lebiler, Muvahhidler, Tolunoğulları, Fatımiler, Eyyübiler, Tahiriler, Saffariler, Gazneliler, Büveyhiler, Selçuklular, Karamanoğulları, Osmanlılar, Harzemşahlar, Çobanoğulları, Karakoyunlular, Akkoyunlular gibi devletlerin tarihlerini içerir (Canatar 1993: 351; Cantimer 2011: 18-23).

Cenâbî'ye ait el-Aylemü'z-zahir fi Ahvâl'il evâli ve'l evâhir'in tercümesi olan Gülşen-i Tevârîh'in Şükrullah ve Ramazân-zâde'nin eserleri gibi muhtasar olarak yazıldığının belirli olaylar dahilinde metindeki örnekleri şunlardır:

Edirne'nin fethi özet olarak “Ve yedi yüz altmış birinci senesinde Atâbeg Şâhîn Lâlâ'yı vâfir asker ile Edirne fethine gönderib sonra kendüsü ardınca varub kendi varmadan Edirne'yi feth itdiler ve âmmeten Rumeli Beglerbegiligin 
dahî Evrenos Beg'e verdi. Ve kendi dönüb Brusa'ya geldi. Ve Lâlâ Şâhîn Filibe ve Eski Zagra'yı feth itdi. Ve yedi yüz altmış üçünde Evrenos Beg, İbsâla ve Malgara'yı feth eyledi. Ve gânîmîn her taraftan Rumeli'ne akın salub şol kadar esîr ve mâl-l ganîmet getürüb Gelibolu'dan Anadolu'ya geçürürler idi ki ta 'bîr olunmaz.” şeklinde ifade edilmiştir. ( Cenâbî Mustafa Efendi, Gülşen-i Tevârih [yz.] Topkapı Sarayı Müzesi Revan Bölümü, No: R.1136, Vr. 224a , 224b .)

Pencik ve Yeniçeri Ocağının kurulması kısa olarak "Bir gün Vezîr Kara Halîl Paşa etitdi ki; "Kitâblarımızda humus-ı mugnîm Beytü'l-mâl'ındır, derler idi. Münâsib olan budur ki Gelibolu Boğazı'nda adam konsun. Her beş esîrden biri alınsun pâdişâha asker ve hizmetkâr olsun" didi. Pâdişâh dahî münâsib görüb öyle eylediler. Ol sebebden az zemânda çok kimesne cem 'olub pâdişâha bunlar ne vechile olmak gerekdir deyincek, pâdişâh dahî bunları ârif-i billâh Hacı Bektâş hazretlerine gönderib "Bunlara du'â eylesün ve bunlara bir alâmet virüb ad koşunlar” deyü buyurdular. Şeyh dahî geydüğü köynegin bir yenin kesüb birinin başına geydirib "Bunlar Yeniçeri olsunlar ve bunların yüzü mehîb olsun, vardıkları yerde yüz ağartsunlar” deyü du 'â eyledi” şeklinde anlatılmıştır (Cenâbî Mustafa Efendi, Gülşen-i Tevârih [yz.] Topkapı Sarayı Müzesi Revan Bölümü, No: R.1136, Vr. 224 ${ }^{\text {.). }}$.

Karamanoğullarının itaat altına alınması yine hülasa biçimde "Ve Karamanoğlu'nda hemşîresi olmagın âna nesne demedi. Tâ kim, Yıldırım Hân Eflâk seferinden dönüb yedi yüz doksan dördünde Gelibolu'dan cihâd niyetiyle geçmiş iken Karamanoğlu nakz-ı ahd idüb Kütahya'yı hisâr idüb ba'z-ı fesâd eyledi. Bu haber Yıldırım Hân'a vâsıl olıcak derhâl dönüb Karamanoğlu'nu kovub, Akçay nâm mevzi 'de yetişüb iki oğluyla tutub kendüsün katl idüb oğulların Brusa Kal 'esi'nde haps eyledi. Ve cemî'an vilâyet-i Karaman'ı alub zabt eyledi. " cümleleriyle açıklanmıştır. ( Cenâbî Mustafa Efendi, Gülşen-i Tevârih [yz.] Topkap1 Saray1 Müzesi Revan Bölümü, No: R.1136, Vr. 225 ${ }^{\text {b }}$ )

Anadolu'da alınan diğer kaleler ise yine muhtasar olarak "Ve gelesi yıl [795] sefer idüb Kâdı Burhâneddîn Sultân Ahmed'in elinden Amasya ve Tokat ve Niksar'ı ve Samsun'u ve Canik vilâyetlerin feth aldl." şeklinde izah edilmiştir. ( Cenâbî Mustafa Efendi, Gülşen-i Tevârih [yz.] Topkapı Sarayı Müzesi Revan Bölümü, No: R.1136, Vr. 225 .)

Şili Kalesinin fethi yine hülasa olarak "Ve yedi yüz yetmiş yedide (797) Şili Kal 'esi feth olunub, Boğazkesen mukâbelesinde Güzelhisâr nâm kal 'a binâ 
olundu. Ve İstanbul tekûruna haber gönderdi ki "İstanbul'u bana vir ve illâ sen bilürsün" didi. Ol dahî havf eyleyüb yılda onbin flori harâc virecek oldu. Ve Istanbul içinde Müslimânlara bir mahâlle virüb ânda kadî ve câmi " nasb olunmă̆a râzı oldu. Bu hâlî Tîmur fitnesine değin bâkî idi.” şeklinde anlatılmıştır. (Cenâbî Mustafa Efendi, Gülşen-i Tevârih [yz.] Topkapı Sarayı Müzesi Revan Bölümü, No: R.1136, Vr.225 b.)

\subsubsection{Hezârfen Hüseyin Efendi "Tenkîh-i Tevârih-i Mülûk"}

XVII. yy'da yaşamış bilgin tarihçi ve yazardır. Doğum tarihi bilinmemekle birlikte doğum yeri İstanköydür. İlköğrenimini İstanköy’de görmüş daha sonra İstanbul'a gelerek eğitimini burada tamamlayarak "Bin fen bilen" anlamında Hezârfen adıyla tanınmıştır. (Bayrak 2002: 174) IV. Mehmed'e tarih dersleri vererek hocası olmuş, Fazıl Ahmet Paşa'nın himayesine girmiş ve onunla birlikte Girit Seferine katılmıştır. (Özdemir, 2007: 11) Ancak ilme olan merakından devlet görevini bırakıp ilimle meşgul olmaya başlamıştır. Bildiği Latince ve Grekçe sayesinde Grek, Bizans ve Roma tarihi üzerine çalışmalar yapmış ve 1691 yılında vefat etmiştir (Öztürk 2015: 129)

Hezârfen Hüseyin Efendi Tenkîh-i Tevârih-i Mülûk adlı eseri IV. Mehmed'e hocalık yaptığı sırada annalistik karakter yerine sistematik bir tarzda; özellikle Yunan ve Roma devirlerini Yunanca ve Latince kaynaklardan yararlanarak hazırlamış ve Vişne-zâde İzzetî Efendi'ye takdim etmiştir ( Lokmacı 2017: 228).

Tenkîh-i Tevârih-i Mülûk içerik olarak bir giriş, dokuz bölüm ve iki hâtimeden oluşmaktadır. Birinci bölüm Pişdâdiler, Keyâniler, Eşkâniler, Sâsâniler ve Batlamyuslar'1 konu edinmiştir. İkinci bölüm Hz. Muhammed'in doğumu, şavaşları ve özelliklerini anlatmıştır. Üçüncü bölüm Dört Halife dönemi ve sonrası olaylarını içermektedir. Dördüncü bölüm Hz. Muhammed'in vefatından sonra kurulan elli iki İslam hükümetini anlatmaktadır. Beşinci bölüm Osmanlı Devleti'nin kuruluşundan IV. Mehmed'e kadar gelen olayları ihtiva etmektedir. Altıncı bölüm Yunan Devleti'nin kuruluşunu konu edinmiştir. Yedinci bölüm Konstantiniyye'nin kuruluşu, bazı yunan filozofları, İstanbul'daki su kemerleri, büyük yangın ve sel, Ayasofya'nın yapılışı, İstanbul'un Müslümanlar tarafından kuşatılması, Hz. Eyyüb'ün vefatı, Karadenizin donması, Ebu Hafs Ömer b. İsa'nın Girid'i fethi, Venediklilerin ve Fransızların Kıbrıs'ı ele geçirmeleri, Rumların Galatayı Cenevizelilere neden temlik eylemelerini anlatmıştır. Seki- 
zinci bölüm Çin, Maçin, Hitta ve Hotin memleketlerinin durumu, Çin'deki Sumatra, Burnoy, Seylan gibi bazı adalar bilgisi hakkında içeriğe sahiptir. Dokuzuncu bölüm Amerika'nın keşfini konu edinmişken hatime kısmında tûl ve arz tayini, hâtimetü'l-hâtime kısmında ise alışverişte narh sisteminin getirilmesi ve elkab-1 selatinden bahsedilmektedir (İlgürel 1998: 545; Lokmac1 2017: 228).

Hezârfen Hüseyin Efendi tıpkı Şükrullah ve Ramazân-zâde gibi eserini neden kısa yazdığını giriş kısmında "Lâkin kütüb-ı tevârihde olan cerâ'id ve fevâ'idin ekseri kebîretü'l cüsse ve kesîretü'l kıssa olub hâtır-ı müstemi 'ağrâz-l kitâb ve hülâsa-i mâfíl'-bâlî kemâyenbağ̂̀ idrâk edemeyüb istimâ 'indan ebâ ve tab' kārî dahî evâi'l-i kelâmı evâhiriyle zabtdan 'âciz kaldı̆̆ sebebden bu za'ylf-l bi kuvvet ve bu nahîf-i bi kudret Hüseyinü'ş-şehîr be-hezârfen tevârih-i bedâyi " ve vakāyi istifsâr ve istihbâr olundukda hîn-i hitâbda hâzır cevâb olmak içün 'ilm-i târîhde murâd olan ma 'ânîyi edâ eder." ${ }^{37}$ şeklinde ifade etmiştir. ( Hezârfen Hüseyin Efendi, Tenkîh-i Tevârih-i Mülûk [yz.] Manisa Yazma Eser Kütüphanesi, NO:5071, Vr. 1 ${ }^{\text {b }}$.) Eserde Osmanlı Tarihindeki belli olayların kısa-özet olarak anlatılmasına örnekler şunlardır;

Bursa'nın fethi kısa bir biçimde "Târîh-i Feth-i Bursa sene 712. Evlâd-ı Emcâd Sultân Orhân ve Sultân Alaeddîn Sultân Osmân Gazî’nin zamân-ı şerîflerinde temam otuz kal 'a feth ü teshîr oldı." ifade edilmiştir. Ayrıca Orhan Bey döneminde alınan diğer kalelerin isimleri verilmeden sadece sayı olarak şu şekilde ifade edilmiştir. "Sultân Orhân zamanında yikirmi bir kal 'a feth olundı." cümleleriyle anlatılmıştır. ( Hezârfen Hüseyin Efendi, Tenkîh-i Tevârih-i Mülûk [yz.] Manisa Yazma Eser Kütüphanesi, NO:5071, Vr. 66ª )

Sultan Murad Gazi döneminde Edirne'nin fethi özet olarak “Gazâ-i mukaddem Lâlâ Şahin'i Rum-ili beglerbegisi idüb Edirne fethine 'asker ile gönderildikde Edirne tekfûrı çıkub 'askeri karşulayub ceng ü 'azîm oldı. Âhir münhezim olub kal 'aya girdi. Sultân Murâd dahî Gelibolu'dan geçüb kal 'ayı Edirne üzerine gelicek Meric suyı taşub tekfûr sandala binüb kaçdı. Kal 'a hâlî kalub ehl-i İslâm zabt eyledi. Fî sene 761" ifadeleriyle açıklanmıştır. ( Hezârfen Hüseyin Efendi, Tenkîh-i Tevârih-i Mülûk [yz.] Manisa Yazma Eser Kütüphanesi, NO:5071, Vr. 67a.)

37- Cümleleriyle mealen; "Fakat tarih kitapların birçoğu çokca kalın ve aynı zamanda tarihi olayları detaylı bir şekilde naklettiğinden, okuyucular tarih kitaplarından istedikleri gibi istifade edemedikleri için, tarihi meselenin evveli ile ahiri arasında bağ kuramıyor ve bunları hafızalarında zapt edemiyorlar. Hezârfen lakabıyla şöhret bulmuş zayif, nahif ve güçsüz olan Hüseyin'in tevârih-i bedâyi‘ ve vakāyi'den faydalanılarak tarihi meselelerin özünü vermiştir. Bu eser hitap anında sorulan sorulara hazır cevap olmak için tarih ilminden murad ve maksad olan menalları kapsamaktadır.” 
Fatih Sultan Mehmed'in İstanbul'u fetih etmesi hülasa olarak "Feth-i Kal 'a-i Kostantiniyye. Fi yevmü'l-erba 'a Cemâziye'l-âhir fì sene 857: Sultân Mehemmed Gazi dört yüz pâre gemi tonadıb deryâ tarafindan ve yetmiş pâre gemi dahi Galata üstünden yelken açub kurıdan çekdürüb Hazret-i Eyyûb civârında olan deryâya getürüb cisr yapulub 'asker geçüb elli gün mikdârı kal' $a-i$ cengin idüb elli birinci gün [?] Çeharşenben bağaya [?] feth ü teshîr olındl. 'Asker-i İslâm mâl-ı ganimete müstagrik oldılar. Fatih İstanbul hakkında hadîsi-i şerîf Resûl salla'llahu 'aleyhi ve sellem [?] dil-pezîr ni 'amü'l-emîr diyü menkuldür. Zât-i [?] es-sefâyı bundan istidâl olunur ki bu beşâret ol-padişâh-ı ferîd ve neferîn 'uluvv-şanına [?] 'aleyhi'r-rahmete'l-mülki'l-mennân fesâkine âlî [?]" şeklinde verilmiştir ( Hezârfen Hüseyin Efendi, Tenkîh-i Tevârih-i Mülûk [yz.] Manisa Yazma Eser Kütüphanesi, NO:5071, Vr. 71ª.).

Yavuz Sultan dönemindeki Mercidabık Savaşı ise "Hazret-i fâtih-i 'Arab u 'Acem yümn-i ikbâlle 'Acem seferine gider iken Misır sultanı Kansu Gavri tâ' 'ife '-i Haleb ve Çerkesîn nakis ile padişah-ı felek dest-gâh hazretlerinin arkurl yoluna gelüb Haleb kurbinde Mercidabik nâm mahalde ceng-i 'azîm olub Kansu Gavri ol-cenkde hâk-i helâki düşdi. Fi Haleb sene 922. “ şeklinde özet biçimde verilmiştir ( Hezârfen Hüseyin Efendi, Tenkîh-i Tevârih-i Mülûk [yz.] Manisa Yazma Eser Kütüphanesi, NO:5071, Vr.74a. ).

Kanuni Sultan Süleyman döneminde fetih edilen Belgrad ve Rodos'un fethi sadece "Feth-i Kal'a-i Belgrad sene 927 der-Ramazân. / Feth-i Rodos sene 929 der-Sefer. " başlık şeklinde ay ve y1l şeklinde verilmiştir (Hezârfen Hüseyin Efendi, Tenkîh-i Tevârih-i Mülûk [yz.] Manisa Yazma Eser Kütüphanesi, NO:5071, Vr.75 b. ).

\section{SONUÇ}

XIII. yüzyılda kurulan Osmanlı Devletinde tarih yazıcılığı XV. yüzyıl başlarından itibaren oluşmaya başlamış ve zamanla gelişimini tamamlayarak genellikle bir padişah dönemi olayları ile sadece Osmanlı devletini konu alan Tevârîh-i Âl-i Osmanlar geleneğine dönüşmüştür. Bununla birlikte bir bütün olarak insanlığın yaratılışından başlayarak içinde bulunulan döneme kadarki olayları konu edinmiş olan umumi tarihler ise nihayetinde diğer devletleri de kapsayan geniş bir yelpazeyi muhteva olarak eserlerine işleyen farklı bir tür olarak yerini almıştır.

Çalışmanın konusunu oluşturan muhtasar umumi tarihlerdeki anlatım tarzındaki tasvirlemelerin ortak özelliği çoğu zaman bir cümle ile alınan yer ve 
alınma tarihi şeklinde verilmiş olmasıdır. Bu durum müelliflerin önceliklerinin olayları kronolojik esaslı oluş sıralamasına göre aktarmak olduğunu göstermesi açısından önemlidir. Büyük seferler olarak adlandırılan savaşlar ise belirli bir plan dahilinde aşamalar şeklinde verilmiştir. Bu aşamalar genellikle özetler şeklinde fetih yapılan yerin coğrafi konumu, feth edilecek yerin önemi, kuşatılacak kalenin vasıflarının kısa anlatımlarıdır. Bununla birlikte savaş öncesinde yapılan hazırlıklar, daha önce fetih edilememe gerekçeleri kısa da olsa de yer yer aktarılmıştır. Savaş esnasındaki büyük mücadeleler ise genellikle kısa ve genel ifadelerle savaşın şanına vurgu ve padişahın yüceltilmesi şeklindedir. Ayrıca fetihler bazen sadece sonuç odaklı aktarıldığı gibi genel olarak sebep-sonuç ilişkisi içerisinde hülasa olarak ifade edilmiştir. Bunun yanısıra kimi zaman sebep-sonuç-mekan üçlemesi içinde sunulduğu gibi yer yer sebep-sonuç-zaman-mekan unsurlarının birlikte verildiği de görülmektedir.

Mevlana Şükrullah'ın “Behçetü’t Tevârih”i XV. yüzyılda kaleme alınmış ve günümüze kadar gelen ilk muhtasar umumi tarih olması açısından önem teşkil etmektedir. XVI. yüzyılda Ramazân-zâde tarafından kaleme alınmış olan Târîh-i Nişâncı Paşa ise kendinden sonra yazılan muhtasar umumi tarihlerden Cenâbî Mustafa Efendi “el-Aylemü’z-zahir” veya “Gülşen-i Tevârîh”i ile Hezârfen Hüseyin Efendi'nin “Tenkîh-i Tevârih-i Mülûk”e kaynaklık etmesi açısından önemlidir. Özellikle Cenâbi ve Hezârfen Hüseyin Efendi özellikle Osmanlının kuruluşundan Kanuni dönemi olaylarına kadarki bilgileri büyük bir oranda değiştirmeden eserlerinde kullanmayı tercih etmişlerdir. Bununla birlikte feth edilen yerleri yer yer Ramazân-zâdeye göre daha da kısaltarak anlatmaları neticesinde muhtasarlık içinde daha da muhtasarlığa yöneldikleri görülmektedir. $\mathrm{Bu}$ bağlamda muhtasar olarak hazırlanan umumi tarihlerinde kendi aralarında muhtasar yazma şekillerinde farklılıkların olduğu dikkate şayandır. 


\section{KAYNAKÇA}

\section{Matbu ve Yazma Eserler}

AHMED RESMİ EFENDİ, Halifetü'r-Rüesâ, İstanbul 1269.

CENÂBÎ MUSTAFA EFENDİ, Gülşen-i Tevârih, Topkapı Sarayı Müzesi Revan Bölümü, No: R.1136.

HEZÂRFEN HÜSEYİN EFENDİ, Tenkîh-i Tevârih-i Mülûk, Manisa Yazma Eser Kütüphanesi, No: 5071.

PEÇEVİ İBRAHİM EFENDİ, Peçevi Tarihi, Unıversity Of Toronto DR 511 P33 V.1.

RAMAZÂN-ZÂDE NIŞÂNCI MEHMED PAŞA, Târîh-i Nişâncı Paşa, Almanya Staatsbibliothek, Berlin, Ms.or.fol.4153.

\section{Araştırma- İnceleme Eserler}

AFYONCU, Erhan (2003), “Osmanlı Siyasi Tarihinin Ana Kaynakları: Kronikler”, Türkiye Araştırmaları Literatür Dergisi (TALID), 1 (2), 101-172.

AFYONCU, Erhan (2009), Tanzimat Öncesi Osmanlı Araştırma Rehberi.

ADEMLER, Betül (2007), Düstürnâme-i Enverî (Dil Özellikleri-Metin), Sakarya Üniversitesi Sosyal Bilimler Enstitüsü, Yüksek Lisans Tezi.

AĞIRAKÇA, Ahmet (2006), "Müneccimbaşı Ahmed Dede", TDV İslam Ansiklopedisi, Cilt XXXIII, 4-6.

AĞIRAKÇA, Ahmet (2014), Müneccimbaşı Ahmed ibn Lütfullah Osmanlı Devleti'nin Kuruluş Tarihi (1299-1481) Câmi 'ü'd-Düvel, Akdem Yayınları.

AKBULUT, Uğur (2006), Osmanlı Tarih Yazıcılarına Göre Tarih ve Tarihçi, Atatürk Üniversitesi Sosyal Bilimler Enstitüsü Sosyal Alanlar Eğitimi Ana Bilim Dalı Yayınlanmış Doktora Tezi.

AKÇAY, Hasan (1999), Ahmedî'nin İskender-nâmesi Transkripsiyonlu Metin, Harran Üniversitesi Sosyal Bilimler Enstitüsü Türk Dili ve Edebiyatı Anabilim Dalı Eski Türk Edebiyatı Bilim Dalı, Yüksek Lisan Tezi.

AKTEPE, M.Münir (1958), “ Hoca Sadeddin Efendi Tacü’t Tevârihi ve Bunun Zeyli Hakkında”, Türkiyat Mecmuası, XIII, 101- 116.

AKTEPE, M.M. (1995), “Sadullah Enverî”, Diyânet İslâm Ansiklopedisi, Türkiye Diyânet Vakfı Yayınları, Cilt XI, 268- 270. 
AKÜN, Ö.Faruk (1998), “Ahmed Vefik Paşa”, Diyânet İslâm Ansiklopedisi, Türkiye Diyânet Vakfı Yayınları, Cilt II, 143-157.

ALMAZ Hasan (2013), Behçetü't-Tevârîh Tarihin Aydınlı̆̆ında Şükrullah Efendi, Mostar Yayınları.

ARSLAN, Mehmet (2003), Mehmed Cemaleddin Osmanlı Tarih ve Müverrihleri-Âyine-i Zurefâ, Kitabevi Yayınları.

ASIM, Necib (1329), “Osmanlı Tarihnüvisleri ve Müverrihleri”, TOEM, I/7 İstanbul 1329, 425-428.

AYCİBİN, Zeynep (2016), Katip Çelebi Fezleke (Osmanlı Tarihi 10001065 / 1591-1655, Çamlıca Yayınları.

AYDIN, Ahmet (2002), “Osmanlı Tarih Yazıcılı̆̆ı”, Türkler Ansiklopedisi XI. Cilt, 417- 425.

AYDEMİR, Mehmed Süreyya (1996), Sicil-i Osmanî, Cilt III. Tarih Vakfi Yurt Yayınları.

AYKUT, Şevki Nezihi (1997), “ Hasanbeyzade ”, Diyânet İslâm Ansiklopedisi, Türkiye Diyânet Vakfı Yayınları, Cilt XVI, 363-364.

AZAMAT, Nihat (1992), Anonim Tevârih-i Al-i Osman, Marmara Üniversitesi Yayınları No: 510, Fen-Edebiyat Fakülyesi Yayınları, No: 24.

BAKIR, Abdullah (2014), Yazıcı-zâde 'Alî, Selçuk-nâme Indeksli Tıpkıbasım, Türk Tarih Kurumu Yayınları.

BALCI, Rüştü (2007), Keşfü'z-Zunûn, An Esâmi'l-Kütübî ve'l-Fünûn (Kitapların ve İlimlerin İsimlerinden Şüphelerin Giderilmesi), I.Cilt, Tarih Vakfi Yurt Yayınları.

BAŞAR, Fehamedin (2002), "İlk Osmanlı Tarihçileri”, Türkler Ansiklopedisi, XI. Cilt, s.409-416.

BAYRAK, Orhan (2002), Osmanl Tarihi Yazarlarl, Milenyum Yayınları.

BAYKARA, Tuncer (2010), Tarih Araştırma ve Yazma Metodu, IQ Kültür Sanat Yayınc1lık.

BAYKAL, Bekir Sıtkı (1999), Peçevi Tarihi, Cilt 1, Kültür Bakanlığı Yayınları, Ankara 1999. 
CANATAR, Mehmet (1993), Müverrih Cenâbî Mustafâ Efendi ve Cenâbî Tarihi I, (Yayımlanmış Doktora Tezi), Ankara Üniversitesi Sosyal Bilimler Enstitüsü İslam Tarihi ve Sanatları Anabilim Dalı.

CANATAR, Mehmet (1993), “Cenâbî Mustafa Efendi ”, Diyânet İslâm Ansiklopedisi, Türkiye Diyânet Vakfı Yayınları, Cilt VII, 351-353.

CANTIMMER, Mehmet Alper (2011), Cenâbî Mustafa Efendi'nin El- 'Aylemü'z-Zahir Fi Ahvali'l- Evâil ve'l- Evâhir Adlı Eserinin Önasya Klsmının Tenkidli Metin Neşri, Sakarya Üniversitesi Sosyal Bilimler Enstitüsü Yüksek Lisan Tezi.

ÇİÇEK, Hikmet (2018), “Ahmed Câvid Bey’in Müntehabât İsimli Eserinde Mehâsinü'l-âsâr ve Hakāikü'l-Ahbâr'1 Kaynak Olarak Kullanma Yöntemi”, Akademik Tarih ve Düşünce Dergisi, İlkbahar 5(14), 377-406.

ÇİÇEK Hikmet (2018), (Vekāyi‘nüvis) Sadullah Enverî Efendi ve Tarihi'nin II. Cildi'nin Metin Ve Tahlili (1187-1197/1774-1783), Atatürk Üniversitesi Türkiyat Araştırmaları Enstitüsü Türk Tarihi Anabilim Dalı Yeniçağ Bilim Dalı, Yayınlanmamış Doktora Tezi.

DAŞ, Abdurrahman (2003), Osmanlılarda Münşeât Geleneği, Hoca Sadeddin Efendi'nin Hayatı, Eserleri ve Münşeâtı, Ankara Üniversitesi Sosyal Bilimler Enstitüsü İslam Tarihi ve Sanatları Anabilim Dalı İslam Tarihi Bilim Dalı Doktora Tezi.

DONUK, Suat (2017), Hadâiku'l-hakâ'ik fì Tekmileti'ş-Şakâ 'ik, Nev 'îzâde Atâyînin Şekâ'ik Zeyli, Inceleme-Tenkitli Metin, (Ed.) ÖRS Derya, I. Cilt, Türkiye Yazma Eserler Kurumu Başkanlığg1.

ERKAN, Davut (2005), Matrâkçı Nasûh'un Süleyman-nâmesi ( 1520 1537 ), Marmara Üniversitesi Türkiyat Araştırmaları Enstitüsü Türk Tarihi Ana Bilim Dalı Yeniçağ Tarihi Bilim Dalı Yüksek Lisan Tezi.

ERKAN, Davut (2011), “ Matrâkçı Nasuh'un Hayatı ve Eserleri Üzerine Notlar", The Journal of Ottoman Studies, XXXVII, 181-197.

FAYDA, Mustafa (2011), “Tarih”, Diyânet İslâm Ansiklopedisi, Türkiye Diyânet Vakfı Yayınları (TDVY), XL, 30-36.

HANCZ, Erich (2007), "Peçeylû İbrahim ”, Diyânet İslâm Ansiklopedisi, Türkiye Diyânet Vakfı Yayınları, Cilt XXXIV, 216-218. 
HALAÇOĞLU Yusuf- AYDIN M.Ahmet (1993), “ Cevdet Paşa ”, Diyânet İslâm Ansiklopedisi, Türkiye Diyânet Vakfı Yayınları, Cilt VII, 443-450.

İLGÜREL, Mücteba (1998), “ Hüseyin Efendi Hezârfen ”, Diyânet İslâm Ansiklopedisi, Türkiye Diyânet Vakfı Yayınları, Cilt XVIII, 544-564.

İPŞİRLİ, Mehmet (2009), “ Selanikî Mustafa Efendi ”, Diyânet İslâm Ansiklopedisi, Türkiye Diyânet Vakfı Yayınları, Cilt XXXVI 357-359.

İPŞİRLİ, Mehmet (2006), "Naîmâ”, Diyânet İslâm Ansiklopedisi, Türkiye Diyânet Vakfı Yayınları, Cilt XXII, 316-318.

KAÇALİN, S. Mustafa (2006), "Mütercim Asım Efendi”, Diyânet İslâm Ansiklopedisi, Türkiye Diyânet Vakfı Yayınları, Cilt XXXII, 200- 202.

KAYA, Nevzat (2001) “Karaçelebizade Abdülaziz Efendi”, Diyânet İslâm Ansiklopedisi, Türkiye Diyânet Vakfı Yayınları, Cilt XXIV, 381-383.

KÜTÜKOĞLU, Bekir (1989), “Ali Mustafa Efendi”, Diyânet İslâm Ansiklopedisi, Türkiye Diyânet Vakfı Yayınları, Cilt II, 414-416.

KÜTÜKOĞLU, Bekir (2002), "Vak'anüvis” Diyânet İslâm Ansiklopedisi, Türkiye Diyânet Vakfı Yayınları, Cilt XXXXII, 457-460.

LOKMACI, Süleyman (2017), “Osmanlı Tarih Yazıcılığında Gazavatnâmeler ve Ebubekir b. Abdullah'1n Şark Seferleri İsimli Gazavatnâmesi”, Atatürk Üniversitesi, Sosyal Bilimler Enstitüsü Dergisi, Haziran 21(2), 665- 677.

LOKMACI, Süleyman (2017), “Hezârfen Hüseyin Efendi’nin Tenkîh-i Tevârîh-i Mülük İsimli Eserinin Fransız Milli Kütüphanesinde Supplement Turc 137 Arşiv Numarası İle Kayıtlı Nüshası Üzerine”, Akademik Sosyal Araştırmalar Dergisi, Yıl 5, Sayı 43, 225-236.

LOKMACI, Süleyman (2015), Solak-zâde Tarihi'nin Tahlili ve Metin Tenkidi, (Yayımlanmamış Doktora Tezi), Atatürk Üniversitesi Sosyal Bilimler Enstitüsü Tarih Anabilim Dalı Yeniçağ Tarihi.

MANAGE, V.L. (1963), “The Menāqıb Of Yakhshi Faqīh”, Bulletin Of The School Of Oriental and African Studies, 26 (1), 50- 54.

ÖZCAN, Abdülkadir (2013), "II. Bayezıd Devri Tarihçiliği ve İlk Standart Osmanlı Tarihleri”, Fatih Sultan Mehmet İlmî Araştırmalar İnsan ve Toplum Bilimleri Dergisi, 2, Güz, 141-153. 
ÖZCAN, Abdülkadir (2003), "Fatih Devri Tarih Yazıc1lı̆̆1 ve Literatürü”, Erciyes Üniversitesi Sosyal Bilimler Enstitüsü Dergisi (İstanbul'un Fethi'nin 550. Yılı Özel Sayısı ), 14, 55-62.

ÖZCAN, A Abdülkadir (2002), "Bosnalı Hüseyin”, Diyânet İslâm Ansiklopedisi, Türkiye Diyânet Vakfı Yayınları, Cilt XXVI, s. 130-131.

ÖZCAN, Abdülkadir (1994), "Düstürnâme-i Enverî”, Diyânet İslâm Ansiklopedisi, Türkiye Diyânet Vakfı Yayınları, Cilt X, 49-50.

ÖZCAN, Abdülkadir (1998), "Heşt Bihişt", Diyânet İslâm Ansiklopedisi, Türkiye Diyânet Vakfı Yayınları, İstanbul 1998, XVII, 271-273.

ÖZCAN, Abdülkadir (2013), “Osmanlı Tarihçiliğine ve Tarih Kaynaklarına Genel Bir Bakış”, Fatih Sultan Mehmet İlmî Araştırmalar İnsan ve Toplum Bilimleri Dergisi, 1, Bahar, 271-293.

ÖZCAN, Abdülkadir (1998), “Abdurrahman Şeref”, Diyânet İslâm Ansiklopedisi, Türkiye Diyânet Vakfı Yayınları, Cilt I,175.

ÖZCAN, Abdülkadir (2003), "Mehmed Çelebi- Ramazan-zâde", Diyânet İslâm Ansiklopedisi, Türkiye Diyânet Vakfı Yayınları, Cilt 28, İstanbul 2003, 449-450.

ÖZCAN, Abdülkadir (2011), “Tevârih-i Âl-i Osmân”, Diyanet İslam Ansiklopedisi, Türkiye Diyânet Vakfi Yayınları, Cilt XL,579- 581.

ÖZCAN, Abdülkadir (2007), “Oruç b. Âdil”, İslâm Ansiklopedisi, MEB Yayınlar1, Cilt XXXIII , 425-426.

ÖZDEMİ, Kerim (2007), Hezârfen Hüseyin Efendi'nin Tenkîhü 't-Tevârîh adlı eserinin Selçukluların Zuhurundan Osmanlı Devleti'nin Kuruluşuna Kadar Geçen Bölümlerin Transkripsiyon ve Değerlendirmesi, Celal Bayar Üniversitesi Sosyal Bilimler Enstitüsü Tarih Ana Bilim Dalı Ortaçağ Tarihi Programı Yüksek Lisans Tezi.

ÖZERGİN, M.Kemal (1963), “Rûhî”, İslâm Ansiklopedisi, Cilt IX, 764765.

ÖZGÜL, İbrahim (2010), Karaçelebi-zâde Abdülaziz Efendi'nin Ravzatü'l-Ebrâr Adlı Eseri (1299-1648) Tahlil ve Metin, Atatürk Üniversitesi Sosyal Bilimler Enstitüsü Tarih Anabilim Dalı Doktora Tezi. 
ÖZTÜRK, Necdet (2015), Anonim Osmanl Kroniği Osmanlı Tarihi (1299-1512), Bilge Kültür Sanat Yayınları.

ÖZTÜRK, Necdet (1999), “Osmanlılar'da Tarih Yazıcılığı Üzerine”, Hasan Celal GÜZEL (Ed.), Osmanl, Yeni Türkiye Yayınları, VIII, 257-261.

ÖZTÜRK, Necdet (2015), Imparatorluk Tarihinin Kalemli Muhafizları Osmanlı Tarihçileri, (Ahmedî'den Ahmed Refik'e), Bilge Kültür Sanat Yayınlar1.

ÖZTÜRK, Necdet (2012), Enverî Düstürnâme, Bilge Kültür Sanat Yayınlar1.

ÖZTÜRK, Necdet (2013), Âşıkpaşazâde Tarihi, Osmanlı Tarihi (12851502), Bilge Kültür Sanat Yayınları.

SAĞIRLI, Abdurrahman (2010), "Süleymanname", Diyânet İslâm Ansiklopedisi, Türkiye Diyânet Vakfı Yayınları, Cilt XXXVIII, 124-127.

SCHMIDT, Jan, (2002), “Künhü’l Ahbar”, Diyânet İslâm Ansiklopedisi, Türkiye Diyânet Vakfı Yayınları, Cilt XXVI, 555-556.

TAHIR, Bursalı Mehmed (1975), Osmanlı Müellifleri, Cilt III.

TEKİNDAĞ, M. C. Şehabeddin (1970), "Selim-nâmeler”, İstanbul Üniversitesi Edebiyat Fakültesi Tarih Enstitüsü Dergisi, 1, 197-230.

TELLİĞLU, Ömer (1994), Müneccimbaşı Ahmed B. Lütfullah'ın Cami'ü'd-Düvel'inden Hamdânîler Kısmının Metin Neşri ve Tercümesi, İstanbul Üniversitesi Sosyal Bilimler Enstitüsü Ortaçağ Tarihi Anabilim Dalı Yüksek Lisans Tezi.

TURAN, Şerafettin (2002), "Kemalpaşazâde”, Diyânet İslâm Ansiklopedisi, Türkiye Diyânet Vakfı Yayınları, İstanbul 2002, XXV, 238-240.

TURAN, Şerafettin (1998), "Hoca Sâdeddin Efendi”, Diyânet İslâm Ansiklopedisi, Türkiye Diyânet Vakfı Yayınları, XVIII, 196-198.

ŞEŞEN, Ramazan (1998), Müslümanlarda Tarih-Coğrafya Yazıcılı̆̆ı, İslâm Tarih, Sanat ve Kültürünü Araştırma Vakfı Yayınları.

TURP, Duygu (2011) Bedâyiü'l Vekâyi (17.yy) Metin-Dizin Ve Inceleme ( Vr. 446a-482b), Marmara Üniversitesi Türkiyat Araştırmaları Enstitüsü Türk Dili ve Edebiyatı Anabilim Dalı Türk Dili Bilim Dalı Yüksek Lisan Tezi. 
ÜNLÜ, Nuri (1990), Cami 'ü’d-Düvel ( II.Bayezıd ve Yavuz Sultan Selim Devri) Tenkidli Metin Neşri, Marmara Üniversitesi Sosyal Bilimler Enstitüsü, İslam Medeniyeti ve Sosyal Bilimler Anabilim Dalı İslam Tarihi Bilim Dalı Doktora Tezi.

WOOHEAD, Cristihen (2010), “Şehnâmeci”, Diyânet İslâm Ansiklopedisi, Türkiye Diyânet Vakfı Yayınları, 456.

YILDIZ, Sara Nur (2012), “ Şükrullah ”, Diyânet İslâm Ansiklopedisi, Türkiye Diyânet Vakfı Yayınları, Cilt XXXIX, 257- 258.

YILDIZ, Emrah (2015), “Osmanlı Devleti’nde Bir Dünya Tarihi Deneyim: Mizanc1 Mehmed Murad ve Tarih-i Umumi'si ", Turklsh History Education Journal (Türk Tarih Eğitimi Dergisi), 2015: 4(2), sayfa 113-135.

YURDAYDIN, Hüseyin Gazi (2003), "Matrakçı Nasuh”, Diyânet İslâm Ansiklopedisi, Türkiye Diyânet Vakfı Yayınları, Cilt XXVIII, 143-145. 
Ramazan KILIÇ

YABANCI DIL ÖĞRETIMINDE ANADİL - HEDEF DIL YAPILARININ BAŞARIYA ETKIsI

Nurullah KIRKPINAR

MIILLİ MÜCADELE YILLARINDA BOLŞEVIZM PROPAGANDASI VEANADOLU BASINI 1919-1922

Nesrin GÜLLÜDAĞ - Halit BAŞ

1452 NUMARALI IZMITT ŞERIYE SICIIL INDE YER ALAN UNVAN VELAKAPLAR ÜZERINE BIR INCELEME

Rukiye ÖZDEMIR - Ahmet AYDIN

OSMANLITARIHYAZICILIĞINDA MUHTASAR UMUMI TARIIHLER ÜZERINE

Muhammet Ali HOROZ

17. YÜZYIL BAŞLARINDA GALATA`Y YA GELENTICARİ ÜRÜNLER VE GALATA GÜMRÜK BÖLGESI

Mayrambek OROZOBAYEV

KIRGIZLARDAKİ AŞIKLIK GELENEĞİNIN YENIDEN DOĞUŞU ÜZERINE

Mine TAŞDEMIR

SA ' DU'LLÂH EL-HALVETI’’YE ATFEDILEN ANONIM KASİDE-İ BÜRDE ŞERHINE GÖRE NEFSIN MAHIYETI VE ÖZELLIIKLERİ 